\title{
A GENERAL PURPOSE TECHNOLOGY AT WORK: THE CORLISS STEAM ENGINE IN THE LATE $19{ }^{\mathrm{TH}}$ CENTURY US
}

\author{
Nathan Rosenberg \\ Manuel Trajtenberg \\ Working Paper 8485 \\ http://www.nber.org/papers/w8485 \\ NATIONAL BUREAU OF ECONOMIC RESEARCH \\ 1050 Massachusetts Avenue \\ Cambridge, MA 02138 \\ September 2001
}

\begin{abstract}
Brent Goldfarb has been immensely helpful throughout the preparation of this paper, most especially in gathering and organizing the material connected with waterpower. Stanley Engerman, Catherine de Fontenay, Kenneth Sokoloff, Peter Temin, Sidney Winter and Thomas Zeller provided astute comments. We are also grateful to participants in the Economic Growth and Policy Program of the Canadian Institute for Advanced Research (CIAR), and to participants in the Science and Technology Workshop of the Stanford Economics Department, for constructive suggestions. We acknowledge with gratitude the financial support provided by CIAR, and by the Israel-US Binational Science Foundation. The views expressed herein are those of the author(s) and not necessarily those of the National Bureau of Economic Research.
\end{abstract}

(C) 2001 by Nathan Rosenberg and Manuel Trajtenberg. All rights reserved. Short sections of text, not to exceed two paragraphs, may be quoted without explicit permission provided that full credit, including (C) notice, is given to the source. 
A General Purpose Technology at Work:

The Corliss Steam Engine in the late $19^{\text {th }}$ Century US

Nathan Rosenberg and Manuel Trajtenberg

NBER Working Paper No. 8485

September 2001

JEL No. N11, N61, O18, O40

\begin{abstract}
The steam engine is widely regarded as the icon of the Industrial Revolution and a prime example of a "General Purpose Technology," and yet its contribution to growth is far from transparent. This paper examines the role that a particular innovative design in steam power, the Corliss engine, played in the intertwined processes of industrialization and urbanization that characterized the growth of the US economy in the late $19^{\text {th }}$ century. Waterpower offered abundant and cheap energy, but restricted the location of manufacturing just to areas with propitious topography and climate. Steam engines offered the possibility of relaxing this severe constraint, allowing industry to locate where key considerations such as access to markets for inputs and outputs directed. The enhanced performance of the Corliss engine as well as its fuel efficiency helped tip the balance in favor of steam in the fierce contest with waterpower. With the aid of detailed data on the location of Corliss engines and waterwheels and a two-stage estimation strategy, we show that the deployment of Corliss engines indeed served as a catalyst for the massive relocation of industry away from rural areas and into large urban centers, thus fueling agglomeration economies, and attracting further population growth. This illustrates what we believe is an important aspect of the dynamics of GPTs, whether it is electricity in the early $20^{\text {th }}$ century or Information Technologies in the present era: the fact that GPTs induce the widespread and more efficient relocation of economic activity, which in turn fosters long-term growth.
\end{abstract}

Nathan Rosenberg

Department of Economics

Stanford University

Stanford, CA 94305-6072

nate@leland.stanford.edu
Manuel Trajtenberg

Eitan Berglas School of Economics

Tel Aviv University

Tel Aviv 69978

Israel

and NBER

manuel@post.tau.ac.il 


\section{Introduction}

The steam engine has long been regarded as the icon of the Industrial Revolution, even though the extent of its singular contribution to growth has been the subject of much debate. A casual excursion into the history of this prime mover and of its vast array of uses suggests that the steam engine fits well the notion of "General Purpose Technologies" (GPTs), and may constitute a prime example of such epochal innovations. From pumping water out of mines and driving the mechanized factories in Britain, to powering virtually the entire industrial sector in the USA by the early $20^{\text {th }}$ century, the steam engine found its way to the major economic activities of the industrial nations over a span of a century. Moreover, steam became in the course of the $19^{\text {th }}$ century the main power source for water and land transportation, breaking the barriers of geographic isolation and bringing about a huge expansion of markets.

We focus in this paper on the Corliss steam engine, a highly innovative embodiment of stationary, high-pressure steam engines, which became the dominant design in the USA for large stationary engines in the late $19^{\text {th }}$ century. Indeed, we shall argue that the Corliss engine played a key role in the fierce contest between waterpower and steam power, particularly in the Northeast. In so doing it helped propel the steam engine to a dominant position in the intertwined processes of industrialization and urbanization that characterized the growth of the US economy in the second half of the $19^{\text {th }}$ century.

The notion of GPTs ${ }^{1}$ rests on the historical observation that whole eras of technical progress and economic growth appear to be driven by a few key technologies: closely following upon the steam engine, electricity quite likely played such a role in the early decades of the $20^{\text {th }}$ century, and information technologies may be doing as much in our era. GPTs unfold over the long haul through a sequence of innovations that take many shapes as distinct embodiments of the basic technology: the engines that powered locomotives

\footnotetext{
${ }^{1}$ See Bresnahan and Trajtenberg (1995), David (1991), Helpman and Trajtenberg, (1998), Helpman (1998), Rosenberg (1976) and (1982).
} 
were radically different from those that pumped water out of mines early on, much as a Pentium processor differs from the integrated circuits of pocket calculators. Thus, by focusing on the Corliss engine we hope to understand the dynamics of GPTs, and in particular the mechanisms by which GPTs play their presumed role as "engines of growth," in the context of a narrowly circumscribed technological and historical setting.

Waterpower, by far the main American power source until the mid $19^{\text {th }}$ century, offered abundant and cheap energy for a wide range of industrial uses. However, waterpower suffered from a crucial limitation: manufacturing plants had to locate wherever topography and climate permitted, and not where key economic considerations such as access to markets for inputs and outputs would have directed. Steam engines offered the possibility of relaxing this severe locational constraint. However, in order for industry to actually relocate on a large scale, the operation of the steam engine had to be sufficiently advantageous compared to watermills. The Corliss engine, with its vast improvements both in fuel efficiency and in key performance characteristics (primarily regularity of motion and the ability to sustain dramatic changes in load), greatly contributed to tipping the balance in favor of steam, particularly in and around New England. ${ }^{2}$ In so doing, then, it helped set off the twin processes of substitution of steam for water, and of relocation of industry from rural to urban environments. These, we hypothesize, turned out to be some of the key pathways by which the steam engine played its role as GPT in the second half of the $19^{\text {th }}$ century.

We shall document these processes with highly detailed quantitative data and econometric analysis, as well as with supporting qualitative historical evidence. The original data come from the Petition that George Corliss submitted to Congress in 1869, requesting a second extension to his highly successful patents. The Petition contains a detailed list of buyers of Corliss engines, with their names, precise location and horsepower, which we supplemented with information about the industrial composition of these users. Our analysis is based on these data, in conjunction with comprehensive

\footnotetext{
${ }^{2}$ Elsewhere the scarcity of appropriate water sites naturally favored steam as the leading prime mover.
} 
data on waterpower (i.e. over 4,000 water sites in the north Atlantic states, with their horsepower and industrial classification), and an array of Census data by counties.

We shall attempt to ascertain with the aid of these data the stringency of the locational constraint imposed by the reliance on waterpower, and the extent to which each of the competing power modes fostered or hindered urbanization. We do that by pivoting on the deployment of Corliss engines and of watermills in the Northeast as of 1870, by county, and looking forward and backwards in time: first, we estimate "adoption" equations for Corliss engines and for watermills as a function of population, physical and human capital and other variables from the 1850 census. Second, we estimate a model of population growth from 1870 to 1900 , as a function of the stock of Corliss engines, watermills, and controls. The findings indicate that Corliss engines did indeed agglomerate in urban centers whereas waterwheels did not. Moreover, subsequent population growth was positively related to the adoption of Corliss engines, and not to the presence of waterpower-based industry.

These results support the hypothesized role of the Corliss in the dynamic interaction between industrialization and urbanization. Freed of the locational constraints of waterpower, manufacturing enterprises driven by steam chose to locate mostly in urban areas, where they could take advantage of agglomeration economies. The presence of Corliss-driven manufacturers contributed to these agglomeration effects, and probably also signaled that more was coming, since Corliss engines were "trend setters", both in that they were deployed in advanced sectors, and in that they were of a larger scale. In time, locations with relatively many Corliss-driven establishments attracted further manufacturers and hence also fostered population growth. By contrast, watermills were not part of such a positive loop: they located in sparsely populated areas to begin with, and failed to attract further economic activity and hence further population to those areas.

The role of the Corliss in precipitating these growth-enhancing relocation processes is, we suspect, far from unique: indeed, it would seem that one of the key channels by which each successive GPT impacts the economy is through the massive 
relocation and reorganization of economic activity that it induces, with concomitant gains in efficiency. Thus, and following the steam engine, electricity brought about the fractionalization of power within factories, enabling the much more efficient (re)location of machines on the factory floor according to the workflow and not to power requirements. The gasoline engine induced a massive relocation of people vis a vis the workplace, extended greatly the radius from which inputs could be drawn, and altered dramatically the loci and scale of commercial activity. And in the present era information technologies appear to be redrawing once again the economic landscape, by shifting the boundaries and location of corporate activity, enabling many of the facets of globalization, and perhaps even making telecommuting a viable option. We still lack a well defined framework to study these GPT-induced relocation processes and their impact on growth. The case of the Corliss steam engine illustrates the potential of taking such route, hopefully providing the stimuli for further research along these lines.

The paper is organized as follows. Section 2 sets the stage by putting the steam engine in the context of the GPT framework. Section 3 describes the key innovations made by Corliss and the main performance characteristics of the engine, and section 4 lays out the data. In section 5 we take a first look at the data, reviewing the range of applications of Corliss engines and their geographical distribution. Section 6 offers an historical perspective of power modes and geography, and formulates the hypothesis to be tested. The adoption equations are estimated in section 7 , and the population growth equations in section 8. Section 9 expands on the role of the Corliss in making possible the vast growth in the scale of industry, with emphasis on rolling mills. Section 10 discusses the subsequent impact of the Corliss: as dominant design in the US, and its impact in Europe. Section 11 offers some concluding remarks. 


\section{The Steam Engine as GPT}

In order to set the stage for the subsequent discussion, it is worth recalling what a GPT is all about: first, it is a technology characterized by general purposeness, that is, by the fact that it performs some generic function that is vital to the functioning of a large number of using products and/or production systems. Second, GPTs exhibit a great deal of technological dynamism: continuous innovational efforts increase over time the efficiency with which the generic function is performed, benefiting existing users, and prompting further sectors to adopt the improved GPT. Third, GPTs exhibit "innovational complementarities" with the application sectors, in the sense that technical advances in the GPT make it more profitable for its users to innovate and improve their own technologies. Thus, technical advance in the GPT fosters or makes possible advances across a broad spectrum of application sectors. Improvements in those sectors increase in turn the demand for the GPT itself, which makes it worthwhile to further invest in improving it, thus closing up a positive loop that may result in faster, sustained growth for the economy as a whole. ${ }^{3}$

The universal character (and hence general purposeness) of the GPT's of the first and second industrial revolutions is easy to grasp: by definition, work involves the transformation of energy from one of its possible states to any other i.e., heat, motion (displacement), light, etc. It so happens that a vast array of disparate economic activities (in transportation, manufacturing, mining, etc.) could potentially be conducted by the application of one particular transformation, namely, that which results in continuous rotary motion, as performed by the steam engine, and later on by the electric motor. ${ }^{4}$ It is in fact an extraordinary coincidence, stemming from a rare combination of physical laws, economic processes and ingenuity (which we do not pretend to fully grasp), that power delivered as rotary motion turned out to be capable of sewing a cloth, lifting us in space,

\footnotetext{
${ }^{3}$ See Bresnahan and Trajtenberg (1995) for a detailed account of the characteristics of GPTs, and Helpman and Trajtenberg (1998) for their impact on growth.

${ }^{4}$ The first steam engines (including Newcomen's) did not operate in a rotary fashion but rather in a straight-up-and-down manner; however, the vast majority of engines since Watt's involved rotary motion, certainly outside mining.
} 
cooling the indoors, and a myriad of other uses. ${ }^{5}$ And indeed, the steam engine proved to be of virtually universal usefulness, quite likely setting a historic high mark for "general purposeness": from mines to water and land transportation to the powering of virtually the entire industrial sector in the USA, ${ }^{6}$ the steam engine found its way to the major economic activities of the industrial nations over a span of almost two centuries. No wonder the symbol of the centennial exhibition in Philadelphia (1876) was a huge Corliss engine, the largest steam engine ever built. ${ }^{7}$

The technological dynamism of the steam engine has been documented extensively elsewhere ${ }^{8}$ and hence we shall not dwell on it here, except for succinct descriptions of the advances that the Corliss design brought about. Identifying and quantifying the unfolding of innovational complementarities is clearly the most important but also the most difficult task in clarifying the role of a technology as GPT: what one would need is evidence to the effect that advances in the GPT foster or enable (complementary) advances across a broad spectrum of application sectors. ${ }^{9}$ We shall attempt to tackle innovational complementarities in the context of the Corliss steam engine in various ways. First and

\footnotetext{
${ }^{5}$ Note that many manual jobs (e.g. sewing, polishing, cutting) could hardly be seen ex ante as natural candidates for replacement by mechanical actions originating in rotary motion, and thus it must have been far from obvious that rotary motion would become such a universal functionality. Even by the mid-nineteenth century there were still very many activities that few would have dreamt to mechanize, let alone automate, with the "prime mover" being the steam engine. Indeed, in many cases the substitution did not make economic sense until ever improving steam engines, and the Corliss among them, delivered such functionality at favorable price/performance ratios.

${ }^{6}$ Taking advantage of the list of buyers from Corliss' Petition and the complementary data gathered, we document in Section 6 the range of uses of the Corliss engine, both in itself and in comparison to that of alternative power sources at the time. In so doing we delineate, at least in an ex post manner, the extent of general purposeness that the steam engine achieved in the wake of Corliss' innovations.

${ }^{7}$ This engine and a companion one, were used to supply the power needs of the Machinery Hall at the Centennial Exhibition of 1876. The pair of engines was rated at a staggering 1400 horsepower, but they normally operated at far below their rated capacity. Although these engines offered nothing especially innovative aside from their great size, they were seen as an appropriate symbol of recent American industrial achievements.

${ }^{8}$ See e.g. Hunter (1985), and the many sources quoted there, primarily of a technical nature.

${ }^{9}$ The case of electric power provides a clear illustration - see du Boff (1967), Rosenberg (1982), and David (1991). Electricity and electric motors diffused rapidly during the first three decades of the $20^{\text {th }}$ century, and it is widely believed that the large productivity gains registered during that period owe a great deal to this process of electrification: the new energy source fostered a more efficient (re)design of factories and a wholesale reorganization of work arrangements, taking advantage of the newfound flexibility of electric power. Indeed, and as mentioned in the Introduction, the fractionalization of power brought about by electricity meant that machines could be placed on the factory floor much more efficiently according to the natural workflow, and not according to their power requirements, as was the case with the steam engine.
} 
foremost, we argue that the improvements embodied in the Corliss engine helped tilt the equilibrium away from water and towards steam as the main source of power in manufacturing, and in so doing it fostered a massive process of relocation of industry, away from remote, isolated locations and into urban centers. The dual processes of industrialization and urbanization that ensued brought about the benefits of agglomeration, and these externalities in turn further encouraged both the growth of cities and the concentration of manufacturing there. Another mechanism was that the Corliss engine allowed for a much larger scale in manufacturing, and with it the realization of scale economies. Lastly, we discuss in some detail the importance of the Corliss engine for rolling mills, a sector that played a key role in metallurgy during the closing decades of the $19^{\text {th }}$ century, particularly in the building of railroads.

We also devoted significant efforts toward searching for evidence of innovational complementarities in the more straightforward sense of the Corliss engine "prompting" improvements in specific user sectors. However, we could not find compelling, first hand evidence to that effect. We did find repeated assertions that the improved regularity of motion delivered by the Corliss allowed textile manufacturers to move up the quality ladder from low-grade, coarse fabrics to finer grades of cotton yarns and other fibers such as wool. There is also some material suggesting that the performance advantages of the Corliss may have prompted the (re)design of more efficient textile mills. The problem is that we could not find the empirical equivalent of a "smoking gun" in this respect, and hence, while believing that the Corliss engine almost certainly played a role along those lines, we base our analysis exclusively upon the other mechanisms.

Examining the Corliss engine as a particular episode in the evolution of a GPT touches also on the fundamental methodological issues of how to assess, more generally, the economic impact of presumed "major" innovations. Fogel's (1964) seminal study of railroads put forward an approach that centered on the painstaking comparison of costs between the new technology and existing best practice, in that case between railroads and water canals. His findings seemed to indicate that the overall economic impact of the advent of railroads, as measured by cost savings expressed as a percentage of GDP, was 
small, and hence professed to demystify the economic importance of any specific innovation (see also Fishlow, 1966).

In our view a methodology that focuses on cost comparisons, and the concomitant cost-savings calculations, by and large misses the deeper point. As previously mentioned, the impact of a general purpose technology on growth operates primarily through innovational complementarities and the positive loop that these set in motion, and not just through cost advantages. Regardless of the size of the cost savings that a new technology might bring about, if it does not prompt down-the-line innovations and related complementary investments across a wide range of user sectors, it will not propel longterm growth, and hence it will not qualify as a GPT. ${ }^{10}$ Conversely, a technology that does exhibit pervasive innovational complementarities may not result in significant cost savings vis a vis its closest substitute, but this latter fact would not necessarily hinder its role as a GPT.

Von Tunzelmann's (1978) detailed study of steam power and British industrialization starts off from a Fogel-type calculation, and also finds that the measurable impact of the steam engine in terms of costs savings was very small as a fraction of GDP in the UK, as of $1800 .{ }^{11}$ However, he goes further and dwells extensively on "backward and forward linkages", the latter notion closely related to innovational complementarities. After examining the use of the steam engine in the cotton industry, in other segments of textiles, and in mining, von Tunzelmann concludes that these forward linkages were of relatively minor importance, at least through the first half of the $19^{\text {th }}$ century. That may well be the case, and von Tunzelmann certainly buttresses his arguments with impressive scholarship. However, his emphasis is still on the impact of changes in power costs on the adoption of mechanical innovations (such as the self-acting mule and the power loom), rather than on other aspects of prime movers, such as reliability of supply, regularity of motion, or locational flexibility. As already suggested,

\footnotetext{
${ }^{10}$ This is as simple as the difference between a once and for all change in levels, and a change in trend.

${ }^{11}$ Actually, von Tunzelmann studied the impact of Boulton \& Watt steam engines, vis a vis all other prime movers, including Newcomen's atmospheric engines.
} 
it is our intention here to move away from costs and shift the focus towards a different set of mechanisms, particularly those related to location.

\section{The innovative attributes of the Corliss engine}

The key novelty of Corliss' engine was its automatic variable cut-off mechanism. What this meant was that the speed of the engine was subjected to precise control by the ability to automatically vary the length of the time period during which steam entered the cylinder. The variation in engine speed was regulated by the governor, which retarded or advanced the point of cutoff in accordance with the rise or fall of the load that was placed upon the engine. This design feature, which made possible a more efficient exploitation of the expansive power of steam, resulted in the best-known feature of the engine: a substantial improvement in energy efficiency. But perhaps even more important was the fact that the engine was also far more "user-friendly" than its predecessors. In particular, it was capable of delivering a continuous, uniform flow of rotary power in spite of sudden changes in the load that might be imposed on the engine. The smoothness of power delivery was very important, albeit in quite different ways, to the largest manufacturing industries of the time: textiles and metallurgy. Crucially, it permitted higher speeds, while at the same time it reduced the likelihood of breakage in threads that was so disruptive in the textile industry. The uniformity of power delivery became increasingly valuable as the industry moved up the quality ladder to more expensive goods. In metallurgy, where huge, abrupt and punishing variations in load were imposed on the engines that were driving the rolling mills, the engine proved capable of adjusting to these variations far better than other engines of the period (see Section 9 below).

The automatic variable cutoff capability of the Corliss engine brought a huge improvement in the efficiency with which the engine exploited the expansive power of steam. This improvement was achieved by the ingenious design and location of the valves and valve gears, a great advance over the earlier, widely-used slide-valve gear that failed to make any use of steam's expansive power. ${ }^{12}$ According to a widespread practice

\footnotetext{
12 For a detailed description of the Corliss engine see Hunter (1985, vol. II, chapter 5, and in particular pp. 256-7).
} 
of the time, fuel efficiency was measured in terms of pounds of coal consumed per horsepower per hour. By this criterion, Corliss' engine was said, in sworn testimony of numerous users in the Petition, to reduce the cost of fuel by a third or more.

But there was much more to the great commercial success and subsequent economic impact of the Corliss engine than the reduction in fuel costs. The ability to provide a smooth and responsive delivery of power was, as already suggested, of special importance in cotton textiles, where achievement of higher speeds was central to productivity improvement and, moreover, where irregularities in speed were very costly, due to the ease with which cotton thread was subject to breakage. ${ }^{13}$ This consideration became very important in allowing American cotton textile firms to move up the quality ladder from low-grade, coarse cotton fabrics to finer grades of cotton yarns in response to the demands of an increasingly affluent consuming public. At the same time, the availability of steam power was a major factor in making possible the migration of large cotton textile mills to the South in the 1880s and 1890s. The South was also a region where the production costs of coarse goods were lower, and the demand for coarse goods greater. Consequently, the New England cotton textile industry found itself increasingly unable to withstand competition from the South in the category of coarse goods, and accelerated its move up the quality ladder in the late nineteenth century.

The Petition exults in detailed descriptions of the operation of Corliss engines in cotton textiles, given in sworn testimonies by users of the engines, such as "the most perfect regulation of speed," (Petition, p. 27), "a more perfect regulation of the speed of the engine, which has given us a larger production of cloth" (Petition, p. 32), "its other crowning excellence, uniformity of velocity," and "an exacter nicety in its governance, than any of [its] predecessors" (Petition, award of the Rumford Medal, pp. 46-7). A textile manufacturer in Pittsburgh reported that "...with the avoidance of thread breakage attending the irregular motion of his old engine brought a savings probably equal to that from reduced fuel consumption, estimated at $\$ 200$ monthly." (Loc. cit.). The extent to 
which Corliss came to dominate the market in the New England cotton textile industry owed a great deal to this specific feature of his engine. The ability to deliver power, not only at a high velocity, but also with a "uniformity of velocity," was a critical competitive factor throughout the textiles sector.

The excellence in the "regulation" of power remained a distinctive attribute of Corliss engines all the way up until the next major power technology that was eventually responsible for the displacement of the steam engine itself. In the earliest years of the use of electricity for lighting purposes, Corliss engines were employed in the generation of electricity. Although they were shortly to be replaced by turbines, Robert Thurston, the most eminent and knowledgeable mechanical engineer in America in the late 19th century, was unstinting in his praise of its "excellent regulation," as compared to other engines in its class. ${ }^{14}$

\section{Data Sources}

\subsection{Data on the Corliss Engine}

Starting from Hunter's (1985) monumental work and the leads that he provides there, we have mapped a wide array of bibliographical and data sources, both primary and secondary, on the steam engine in general and the Corliss engine in particular. ${ }^{15}$ As it turned out though, the American patent system was to play an especially important role in this project. George Corliss was a prolific inventor who obtained many patents and, moreover, was involved in protracted litigation and other legal matters related to these

\footnotetext{
13 "Increase of speed of spindles is by far the most effectual factor in obtaining this result [reduction in costs]; and hence it is that any increase of speed that can be obtained without other disadvantages is in the line of economy, regardless of the increased cost of power it may involve." Sheldon (1892).

14 "Corliss engines are now very frequently adopted in electric lighting, and are always belted to the dynamos. Their excellent regulation is as important a feature in this application, as is their economy in use of steam...(T)hat these engines can be made to give very perfect uniformity of rotation will be evident, when it is stated that the writer, in testing engines of this class, has found that the variation of speed was so slight as to be practically inappreciable, even when the amount of work thrown on or off, was a very large proportion of that done by the engine when working at its rated power." Thurston (1884), p. 23.

${ }^{15}$ One of the main sources is the collection of Corliss Papers at Brown University. Corliss became a very prominent figure in his time, and had a long time association with Brown University (located in his home town, Providence, RI). As a consequence, the Richard Hay Library at Brown University put together and maintains a special collection of the Corliss Papers, which includes about 900 original items, ranging from business contracts ,to letters, to newspapers clippings.
} 
patents, a fact that generated a large amount of documents of which many have survived. Corliss' main patents on the improvements to the steam engine expired in 1863, but he managed to secure a seven-year renewal. In 1869 he petitioned for yet another renewal, which was turned down by Congress.

One of the happy consequences of Corliss' unsuccessful request is that the formal petition that he submitted to Congress contains detailed information concerning his extensive business activities up to that date. ${ }^{16}$ In particular, the petition contains a list of 257 buyers of Corliss engines, including the names of the firms, their location (city and state) and the horsepower of their engines. It also contains testimonies of several of these buyers, spelling out the advantages of the Corliss engine in their mills (some with precise calculations of cost savings), an extensive argumentation of why the extension is warranted, a detailed account of litigation expenses, etc. The petition is a fascinating historical document that provided the initial impetus for this project, and the list of buyers in it is what made our quantitative analysis possible.

A great deal of our research effort has been directed at ascertaining the industrial sector to which each buyer who appears in the Petition's list belonged, a task that proved to be exceedingly difficult, since it involved searching for information on firms that operated sometime during the period 1850-1870, many of which have left no paper trail. We have relied for that purpose on several sources: archival materials at several libraries, city directories of the time (for some of the major cities where these firms operated), directories of New England Manufacturers, business histories, county histories, etc. We have managed to successfully classify 163 out of the 257 buyers (63.4\%), who represent, however, $73 \%$ of the total horsepower installed. We present in Appendix 1 a sample page from the list of buyers, including our industrial classification, sources, etc.

\footnotetext{
${ }^{16}$ The Petition was published in 1870 as a short booklet, in Providence, RI (see Corliss, 1870).
} 
It should be emphasized that the list of 257 buyers in the Petition, having a stock of about 470 engines, ${ }^{17}$ is not comprehensive: it includes only those who were prepared to support Corliss' petition for patent extension (see Appendix 2). According to Hunter, about 1,200 Corliss engines with 118,500 horsepower (henceforth "HP") were sold up to 1869, of which 25,000 HP were sold by licensees (Hunter 1985, p. 282). In fact, there is some detailed information in the Petition about licensees, and in particular, about the royalties paid by them to Corliss: ${ }^{18}$

\begin{tabular}{|l|l|c|c|}
\hline \multicolumn{4}{|c|}{$\begin{array}{c}\text { Corliss Licensees, reported in the Petition } \\
\text { (sorted by royalties) }\end{array}$} \\
\hline & \multicolumn{1}{|l|}{ Engines Builder/location } & Engines & Royalties* \\
\hline 1 & Miller \& Allen, Chester, PA & 103 & 25,173 \\
\hline 2 & $\begin{array}{l}\text { H.S. Fairbanks, agent of Foundry and } \\
\text { Taunton, } \\
\text { Machine Co., }\end{array}$ & 57 & 22,703 \\
& MA & & \\
\hline 3 & William A. Harris, Providence, RI & 57 & 14,462 \\
\hline 4 & Goss \& Lombard & & 5,848 \\
\hline 5 & J.M. Poole \& Co. & & 3,929 \\
\hline 6 & Wood \& Mann Steam Engine Co. & 2,052 \\
\hline 7 & Atlantic Works & & 942 \\
\hline 8 & C. \& J. Cooper \& Co. & & 700 \\
\hline 9 & S.C. Forsaith & 552 \\
\hline 10 & Woodruff \& Beach & 250 \\
\hline *These are total royalties, including amounts due, as reported in the \\
Petition (cents rounded up).
\end{tabular}

However, we could not incorporate these (still very partial) data in the econometric analysis, since we do not know who were the buyers of the engines sold by these licensees. In addition, Corliss-type engines representing some 60,000 HP were produced and marketed by other manufacturers infringing Corliss' patent rights (Hunter, 1985). Thus, in terms of HP, the listing in the Petition (our "sample") with a total of 46,934 HP, constitutes $50 \%$ of the engines built by Corliss himself up to $1869,40 \%$ of the engines

\footnotetext{
${ }^{17}$ The list consists of buyers, not of single engines, and we know that many of them owned more than one engine. According to the figures in Hunter (1985), Corliss engines averaged $100 \mathrm{HP}$ each; the list in the Petition totals 46,934 HP, and hence we infer that the list comprises about 470 engines.

${ }^{18}$ Corliss states in the Petition that his receipts for royalties involved payments from 11 engine builders, "...seven of whom, having manufactories in Rhode Island, Pennsylvania, Massachusetts, Delaware, New
} 
built by Corliss and the official licensees, and $26 \%$ of the total stock of Corliss engines including those sold by infringers.

The coverage of the Petition list is thus quite wide but, can we presume it to be a representative sample of the population of Corliss-type engines built by 1870 ? There are two concentric issues regarding what "representative" means: the first is, do the buyers who signed the Petition constitute a random sample of those who purchased engines from Corliss himself? Secondly, is the Petition's list representative of all Corliss-type engines sold, including licensees and infringers? It is important to note from the outset that the analysis that we shall perform here relies primarily on the location of Corliss engines and of water-powered sites (i.e. on the distribution of engines and sites by county). Thus, the issue of whether a sample of Corliss engines is "representative" or not is taken to mean whether or not the sample may suffer from noticeable biases with respect to location.

Regarding the first question, we know that the buyers of Corliss engines were engaged in a long-term relationship with Corliss, in that the latter provided maintenance, parts, upgrades, and perhaps also future additional engines. By signing the petition these buyers presumably improved the chances of getting better "service" from Corliss in the future. Thus, we expect that buyers having a larger number of engines, those more likely to acquire further engines in the future, or those for whom "uptime" was more important, would have been more prone to sign. However, and as far as we have been able to ascertain, these attributes were not correlated with location. The working assumption is thus that the willingness of buyers of Corliss engines to join in signing the petition (and hence the probability of appearing in our sample) had little to do with their specific county location. The one possible exception is Providence, RI, Corliss' hometown, and the city with the largest number of listed buyers in the Petition: the close proximity to Corliss may have induced a larger number of them to sign, and hence we shall regard this observation as a potential influential outlier.

York and California, have been at liberty to build as many engines as they pleased, of any size they pleased, to be located wherever they pleased, and to get any price for the same they could...” (Petition, p. 21). 
Engines built by Corliss himself accounted as said for just about $26 \%$ of all Corliss-type engines deployed by 1870 , and hence the second question is to what extent our list of buyers is representative (once again, in the geographic sense) not just of those who purchased engines from Corliss, but of all Corliss-type engines built, including licensees and infringers. We discuss this issue extensively in Section 8 below, and conclude that the data may indeed suffer from some specific selectivity biases, but either we can take care of it point wise (as in the case of Providence, RI), or the biases are likely to work against our hypothesis (as in the case of eastern Pennsylvania), and hence would not impair the validity of the econometric analysis.

According to the 1880 Census, there were 40,191 steam engines in the US by 1870 , displaying a total capacity of 1.2 million HP. The vast majority of them were very small though, with only 5 to $25 \mathrm{HP}$. Corliss-type engines, with 180,000 HP (including infringers) accounted for $15 \%$ of total steam power, ${ }^{19}$ but they were much more powerful than the run-of-the-mill engines, averaging $100 \mathrm{HP}$ as opposed to a mean HP of 30 for all steam engines. After the denial of the extension of patents in 1870 there was rapid entry into the manufacturing of Corliss-type engines, and in fact the Corliss engine became the dominant design of stationary engines for industry (see Section 12.1). Indeed, by the end of the century Corliss-type engines still accounted for just $10 \%$ of the total number of engines in the manufacturing sector, but they represented a staggering $46 \%$ of the total horsepower. ${ }^{20}$

\subsection{Data on Water Power}

In order to be able to contrast the spread and impact of the Corliss steam engine to waterpower, we needed data on water wheels at a level of "resolution" similar to that of the Corliss data. We found that in the Census' "Reports on Water-Power" for 1880 (Census, 1885), containing a comprehensive listing of sites in the US that operated water wheels, with highly detailed data for each: river/stream, location (county), kind of manufacturer, number of mills, HP, etc. (see Appendix 3). Except for a handful, all

\footnotetext{
${ }^{19}$ In New England alone the Corliss engines listed in the Petition amounted to 27,797 HP, which accounted for $18 \%$ of the total steam power in the region, $153,000 \mathrm{HP}$.
} 
Corliss engines listed in the Petition were sold in the North and Mid-Atlantic states, ${ }^{21}$ and hence we took from the Census's Water-Power Report data on the sites located in those states. The data on these 4,716 sites were entered into spreadsheets, followed by extensive editing, filtering, consolidation, etc. ${ }^{22}$ The next stage consisted of aggregating the data by county, which essentially meant summing up the number of mills per county and the HP of those mills. ${ }^{23}$ We also consolidated the textual forms describing the type of manufacturer, and matched the unified fields so created to the industrial classification used in the Censuses of Manufacturers of the late 1800's. ${ }^{24}$

\subsection{Census Data}

We complemented the data on steam engines and waterpower with demographic data and data on manufacturing by county, from the censuses of 1850-1870, as well as population counts by county for 1880-1900 (see Appendix 4). The census data were taken from the internet site of the Inter-university Consortium for Political and Social Research (ICPSR), in Ann Arbor, Michigan (see http://www.icpsr.umich.edu/index.html), as viewed for browsing at the site of the University of Virginia Library, http://fisher.lib.virginia.edu/census/. Aside from population counts, these data comprise variables on human capital, wealth, taxes, and manufacturing that we deem relevant for the location of power sources (steam and water). We have also compiled data on the population of each of the 87 towns and cities where Corliss engines were located, from 1860 through 1910. We use these more specific population data just for descriptive purposes, and for a preliminary analysis confined to these locations (we could not use these data for the full-scale analysis since we did not have data for waterpower by localities, only by counties).

\footnotetext{
${ }^{20}$ See 1899 Census of Manufacturers, p. 255, footnote 5.

${ }^{21}$ To be precise, these include: Maine, Vermont, New Hampshire, Massachusetts, Rhode Island, Connecticut, New York, New Jersey, Pennsylvania, Delaware and Maryland.

${ }^{22}$ The data entry and editing process were lengthy and arduous, both because the data had to be transcribed from a small-print, low-quality copy, and because the way the information is displayed in the original listing is by no means uniform.

${ }^{23}$ We relied for that purpose on "net H.P." and "utilized H.P. In some 20 entries (for Merrimack, MA and $\mathrm{NH}$ ), the figure reported is "Gross H.P.", which we converted to "net H.P." using the conversion ratio of 0.73 as suggested on page 37 of the section "Waterpower in Eastern New England", U.S. Census (1885).
} 
Summing up, our data comprise, $(i)$ the stock of (a large sample of) buyers of Corliss steam engines as of $1870,{ }^{25}$ and in particular the geographical location of these buyers and the installed HP, as well as their industrial composition; (ii) the location of all water-powered sites and their HP as of 1880, and their sectoral composition; (iii) demographic, human capital and wealth indicators and manufacturing data for 1850, 1860, and 1870, and population counts for every decade 1850 - 1900 (all these variables are by county, for the 11 North and Mid-Atlantic states); and (iv) population data for the towns and cities with Corliss engines.

\section{A First Look at the Data}

\subsection{Range of applications}

As mentioned above, one of the key characteristics of a GPT is that a wide and expanding range of sectors adopts it, so that the dynamic interaction between the GPT and the user sectors has economy-wide repercussions. The steam engine had in the course of 2 centuries a very wide array of users, primarily in manufacturing, transportation and mining. The Corliss was as said a stationary engine, and a relatively powerful one at that, and hence most of its users were in the manufacturing sectors. As already mentioned, we managed to gather information on the economic activities of $63 \%$ of the buyers appearing in Corliss' 1869 Petition (representing 73\% of the HP), assigned them to 51 "subsectors", and aggregated them up into 17 two-digit sectors as they appear in the standard industrial classification of the late $19^{\text {th }}$ century censuses (see Appendix 5). ${ }^{26,27}$

\footnotetext{
${ }^{24}$ There were over 400 different textual forms for "type of manufacturer" (e.g. from "bleachery" and "bleaching and dyeing", to "wheelbarrows" and "wheelwrighting"), which we consolidated into the then standard 21 industrial sectors.

${ }^{25}$ It is really for 1869 , but we shall refer to it as 1870 , so as to make it fit the decennial pattern of the other data.

${ }^{26}$ The list of sub-sectors does not correspond to any preexisting classification, but rather we largely adopted the industrial categories that emerged from the data as obtained from the primary sources. That is, if we found in a city directory that a given firm was engaged in the production of "cotton goods", that is the way it appears in the list. Beyond that we just did some rather straightforward consolidation, such as lumping together "Iron" and "Iron Works", "Metal" and "Metal Works", etc.

${ }^{27}$ For some of the buyers we knew only that they were engaged in manufacturing, or that they ran a mill. Since some others were engaged in non-manufacturing, we kept in Appendix 4 the distinction between just "manufacturing" or "mill" (lumped into "unknown type of manufacturing"), and those for which we know nothing ("classification not available").
} 
Appendix 5 and Table 1 make it clear that the Corliss engine was indeed used in a very wide range of applications, covering most of the spectrum of productive activities that required a central power source at the time. ${ }^{28}$ One important further use of the Corliss engine not listed in the Petition (since it happened after 1869) and hence not reflected in the tables was in urban water systems. Corliss built a large pumping engine in 1878 for the Pawtucket, Rhode Island waterworks system, which became a model and landmark for efficiency, scale and fuel savings. By the turn of the century, this type of engine had become standard in urban waterworks systems (see Hunter, p. 299), thus directly impacting the process of urbanization of the US.

Table 2 compares the distribution of Corliss engines, by sectors, to that of water power and of steam power in general (the latter inclusive of the Corliss, but recall that Corliss engines constituted just $15 \%$ of total steam power by 1870). The differences are quite striking: about $70 \%$ of Corliss engines' HP was deployed in Textiles and in Primary Metals, as opposed to just $18 \%$ of waterpower, and $25 \%$ of steam power generally. At the other end, Food \& Kindred Products and Lumber \& Wood Products accounted for 68\% of waterpower and $51 \%$ of steam power, but just for $4 \%$ of the Corliss engines' HP. ${ }^{29}$ To this we should add Machinery, which was the third largest user of Corliss engines in manufacturing (with $5.6 \%$ of HP), but ranked only $6^{\text {th }}$ for waterpower $(2 \%)$, and $5^{\text {th }}$ for steam power $(4.8 \%)$. Notice that the distributions of steam power and of waterpower across sectors are much more similar to each other than any of them is to the distribution of the Corliss. Thus, as of 1870 it was not so much steam per se that was different from water in terms of industrial composition (and similarly in terms of scale and geography);

\footnotetext{
${ }^{28}$ Recall though that this constitutes only a partial picture of the range of applications of Corliss engines, both because we managed to classify only $63 \%$ of the buyers appearing in the petition, and because these represent only about $26 \%$ of Corliss engines manufactured up to 1869 , including licensees and infringers (i.e. the buyers classified account for just about $15 \%$ of all Corliss engines). Thus, ours almost certainly understates the actual range and variety of applications.

${ }^{29}$ Some of these differences are linked to geography: if we restrict ourselves to the North and Mid Atlantic States (those where Corliss Engines were sold), then the share of waterpower deployed in Textiles and Primary Metals rises to $27.5 \%$ (from 18\% nationwide), whereas the share of Food \& Kindred and Lumber $\&$ Wood drops to $48 \%$ (from $68 \%$ nationwide). Still, the remaining differences are very large.
} 
rather, it was the new type of steam engines, starting with the Corliss, that would make the difference.

Textiles, Primary Metals, and Machinery were undoubtedly key sectors propelling the process of industrialization of the late $19^{\text {th }}$ century, with Primary Metals supplying critical inputs both to manufacturing at large and to the rapidly expanding railroad system (see Section 11.1 below). By contrast, Food \& Kindred Products and Lumber \& Wood were two of the more traditional, technologically laggard industries, and consisted mostly of innumerable small mills that served primarily local needs. The Corliss was thus squarely positioned at the forefront of the incipient process of industrialization as of 1870, and in fact it anticipated later shifts in the locus of power deployment:

\begin{tabular}{|l|c|c|c|c|c|}
\hline \multicolumn{1}{|c|}{ Sectors } & \%o of Corliss & \multicolumn{4}{c|}{ \% of Steam Power } \\
\cline { 4 - 6 } & HP - 1870 & 1870 & 1890 & 1900 & 1910 \\
\hline $\begin{array}{l}\text { Textile Products and Primary } \\
\text { Metals }\end{array}$ & 69.1 & 24.7 & 30.2 & 34.1 & 34.0 \\
\hline $\begin{array}{l}\text { Food \& Kindred and Lumber \& } \\
\text { Wood }\end{array}$ & 4.1 & 51.1 & 36.9 & 35.3 & 32.6 \\
\hline
\end{tabular}

Thus, while Textile Products and Primary Metal accounted for just 25\% of total steam power in 1870 , their share grew to $34 \%$ by the turn of the century, and conversely, the share of the "traditional" sectors declined steeply from over a half to about 1/3.

\subsection{The geographic distribution of Corliss engines: is the Petition list a representative sample?}

The 257 Corliss buyers listed in the Petition were spread across 87 different locations (towns, cities), belonging to 48 counties, in 14 states (see Appendix 6). The most significant feature of the localities with Corliss engines was that they were overwhelmingly urban (i.e. had populations of at least 2,500 people): $95 \%$ of the 87 localities with Corlissdriven establishments were urban, whereas for the US as a whole only $26 \%$ of towns were urban. Moreover, Corliss engines were concentrated in very large urban centers: as Appendix 6 reveals, the average population size of the five cities with the largest share of 
Corliss HP was of 334,797, compared to an average population of 42,156 for all of the 87 adopting localities. ${ }^{30}$ These 5 cities (Providence, Philadelphia, Boston, Pittsburgh and New York) commanded $44 \%$ of the total HP of Corliss engines, and $37 \%$ of the buyers.

Table 3 shows the distribution of Corliss engines and of watermills across states, within the North and Mid Atlantic region. Corliss engines were much more geographically concentrated: the 3 top states, Massachusetts, Pennsylvania and Rhode Island accounted for $78 \%$ of Corliss HP, whereas the three top states in terms of waterpower, New York, Massachusetts and Pennsylvania accounted for $56 \%$ of the region's water HP. Notice that the most significant difference between the two power sources is Rhode Island, which accounts for $23.3 \%$ of Corliss' HP, but just a trifle $1.4 \%$ of water power. As it turns out, both are in a sense outliers: On the one hand, it is quite likely that the fact that George Corliss resided in Providence, RI, contributed to the rapid adoption of Corliss engines there, and that this close proximity may also have made it easier to contact buyers and to persuade them to sign the Petition (Providence had the largest number of buyers in our data, 34, and the most HP). On the other hand, and as revealed in the regressions below, waterpower clearly failed to take hold in Rhode Island, relative to other states in the region. Thus, and mindful of the possibility that it might be an influential outlier, we shall conduct the econometric analysis with and without the observation for Providence.

If Providence may overstate the deployment of Corliss engines in that region, we have some fragmentary evidence indicating that our data may understate the adoption of Corliss-type engines in Pennsylvania, and more specifically in locations where iron and steel were thriving at the time. Thus, we know from the Petition that one of Corliss' principal licensees, Miller \& Allen, was located in Chester, Pennsylvania, and built 103 Corliss-type engines in the course of the 1860s (these are not included in our data). We do not have specific information on those who purchased engines from Miller \& Allen, but we know quite a bit about Chester as a manufacturing center at the time. Chester was expanding extremely rapidly in the decades of the 1860s and 1870s, when its population more than tripled (from 4,600 in 1860 , to 15,000 in 1880). Its location, immediately

\footnotetext{
${ }^{30}$ These figures are for 1860 , which is a more natural reference point, given that we are talking about Corliss engines that were sold over the period 1850-69.
} 
adjacent to Philadelphia, the largest manufacturing center in the country, and on navigable waterways that connected it to the iron works of eastern Pennsylvania, was ideal for shipbuilding. By 1870 Chester had the largest shipyards in the US as well as a diversity of manufacturing firms, including 25 textile mills, the large Eddystone Print Works (see V. Clark, II, 146-7), and a large number of iron-using firms. Miller \& Allen's establishment, in addition to its manufacture of steam engines, also built boilers, shafting, gearing, and rolling mill machinery (see Corliss' Petition, p. 35).

Some further evidence from Conshohocken, PA, strengthens the presumption that our data may fall far short in the count of Corliss engines in Pennsylvania. The Wood enterprises, which had moved to Conshohocken in 1832, included in the 1850s the Schuylkill Iron Works and the Conshohocken Rolling Mill, and came to include also, and intriguingly, the Corliss Iron Works, which was built in 1864 and was eventually incorporated as the J. Wood \& Brothers Company in $1886 .{ }^{31}$ It is, at the least, reasonable to suppose that Corliss had some sort of close business connections of a metallurgical nature with the Wood family, who may have manufactured Corliss-type engines.

Thus, it is quite likely that a large portion of the iron and steel industry in eastern Pennsylvania, which had previously drawn their power from the water flow off the eastern slopes of the Allegheny mountains, acquired their first steam engines, if not from Corliss himself, then from Corliss licensees or perhaps from infringers in southeastern Pennsylvania. This happened at a crucial time, when the region made its transition from waterpower to steam engines, rolling mills, and blast furnaces fed by anthracite coal. ${ }^{32}$ Our data, confined to the buyers listed in the Petition, may therefore substantially understate the adoption of Corliss-type engines in that region. However, the region experienced at the time very rapid population growth, and therefore the fact that our sample may undercount the number of Corliss engines deployed there would militate against our hypothesis and hence would not affect the validity of our findings. Still, we should be mindful all along of the data limitations (and possible biases) imposed by the exclusive reliance on the Corliss engines listed in the Petition.

\footnotetext{
${ }^{31}$ The information about Wood draws upon archival records of the Hagley Library, Wilmington, Delaware and Lesley (1859).

${ }^{32}$ See Chandler (1972), for the critical role played by rolling mills powered by steam in Pennsylvania, during the thrust towards industrialization in the second half of the $19^{\text {th }}$ century.
} 


\section{Steam, water and geography: an historical perspective}

In 1829, a full 60 years after James Watt took out his critical patent on the improved steam engine, Zachariah Allen, of Providence, R.I., was still able to paint a bucolic image of American manufacturing, an image that involved no mention of the steam engine. American manufacturing activities, he pointed out, "are all carried on in little hamlets, which often appear to spring up in the bosom of some forest, gathering around the water fall which serves to turn the mill wheel" (Allen, 1829, p. 352). The McLane Report of 1832, with extensive quantitative data (although still incomplete in its coverage), described a manufacturing scene that was powered almost entirely by water. If one excludes the area around Pittsburg, where there was an abundance of readily accessible coal, no more than 4 of the 249 firms in America that had a capitalization of over $\$ 50,000$ were dependent for their power on steam engines. In fact, outside of the Pittsburg area, as Chandler has pointed out, "...more firms reported the use of wind and mule power than steam" (Chandler, 1977, pp. 61-2).

The limited intrusion of the steam engine into the American manufacturing scene during the following decade may be readily calibrated by an examination of the 1838 Treasury survey of steam engines (U.S. Congress, 1838). According to this report, nearly $60 \%$ of all power generated by steam was accounted for by steamboat engines, and a further $5 \%$ or so by railroad locomotives. Thus, only about one-third of all power generated by steam engines in 1838 was accounted for by manufacturing; this amounted to just 36,100 horsepower, which constituted a trifling $5 \%$ of total power used in manufacturing (see Figures 1 - 3). Drawing upon the data of the 1838 Report, Peter Temin concludes that "...steam-engine construction in 1838 was a small-scale business carried on for a predominantly local market," a conclusion that would appear to be reinforced by the fact that the largest single category of users of stationary steam engines in 1838 was sawmills (Temin, 1966, p. 190). The data show, surprisingly at first glance, that Louisiana was a heavy user of stationary steam engines in 1838. This prominence was due to the absence of waterpower sites in southern Louisiana, and the urgency of crushing the sugar cane immediately after it had been cut. 
Figure 1 shows the tremendous growth of power deployed in manufacturing for the USA as a whole during the second half of the $19^{\text {th }}$ century; in fact, power use increased at a staggering average annual rate of $4.7 \%$ throughout those 50 years. This of course mirrors the rapid growth that took place in manufacturing itself, and in fact constitutes a lower bound for it, since the efficiency in the use of power also increased during that period. The figure also makes it clear that it was indeed steam power that led the growth spur throughout that period: starting from a bare $5 \%$ of total power in 1838 , it overtook water by the late 1860 s, and reached a peak of over $80 \%$ by the turn of the century, when electricity started to diffuse rapidly. Less noticeable in the figure (because of the scale) but not less important, water power kept increasing in absolute terms up to 1910, and in fact total water hp deployed in manufacturing was twice as much in 1900 as in 1850 .

The picture that emerges is thus of a rapidly advancing power technology, the steam engine, that made possible the growth of manufacturing (and hence of the economy as a whole) during the second half of the $19^{\text {th }}$ century, by providing it with an increasing fraction of its power needs. The Corliss engine entered the scene by mid century, and our data cover roughly the two decades 1850-70, which as Figure 1 reveals was the period of intense competition between the two power sources. In the course of that period the Corliss became the dominant design for large, stationary steam engines in manufacturing, certainly after the expiration of his patents in 1870 . This then is the backdrop of our study: the takeoff of industrialization in the USA, which is inextricably linked with urbanization, as steam and water fiercely compete for primacy in the process.

The first thing that needs to be said about the limitations of waterpower is that its location and kinetic potential were largely (but not entirely) fixed by geology and hydrology. It is a familiar part of the story of nineteenth century American industrial development, that the westward movement of a growing population found itself in terrain where waterpower locations were far less abundant than they were east of the Appalachians. To this extent the westward movement after the Civil War rendered an 
increasing reliance on steam, at the time the only available alternative, quite unavoidable. That was not quite the case in the north Atlantic states: as Figure 2 reveals, the total horsepower generated from water in New England continued to increase right into the early twentieth century through a combination of measures, including the introduction of new and improved turbines, but also through exploitation of marginal power sites and through improvements in dam engineering. ${ }^{33}$ Thus, in New England steam overtook water as the dominant power source only in the mid $1880 \mathrm{~s}$, whereas in the rest of the US that happened more than two decades earlier (see figure 3).

Several factors played a role in the century-old contest between steam and water power: exogenous movements (and growth) of population, the availability of water sites and the rather complex issue of water rights (Horwitz, 1977, pp. 34-40). advances both in the technology of water power and of steam engines, transport costs (for fuel), etc. But the more subtle part of the story of the shift to steam is associated with the growth of cities and with the advantages of the urban concentration of manufacturing industries (see Krugman, 1991). ${ }^{34,35}$ As the economic benefits of urban agglomeration increased during the second half of the $19^{\text {th }}$ century, and as the transportation network (primarily the railroads) widely expanded in scope and density, static cost comparisons between steam and waterpower became progressively less germane to decision making with respect to choice of prime mover. ${ }^{36}$ Rather, location became increasingly compelling: waterpower was typically not available in urban locations and, for the most part, it was not available on the scale that was required. Moreover, the Corliss engine eventually made steam power available on terms that compared favorably not only with steam engines of other designs, but also with waterpower even in locations where such power was plentiful.

\footnotetext{
${ }^{33}$ In fact, total water hp in New England doubled since the early 1870s to 1910.

${ }^{34}$ As Sokoloff (1988) has convincingly demonstrated through the use of patent records, inventive activity in the first half of the $19^{\text {th }}$ century was closely related to urbanization and the associated growth of markets. ${ }^{35}$ Urbanization was already proceeding rapidly in the years preceding the Civil War. In 1820 there were only 12 cities in the US with a population in excess of 10,000, and only 2 whose numbers exceeded 100,000 . In 1860 there were already 8 cities with over 100,000, and the population of New York City exceeded 1 million.

${ }^{36}$ In this sense, much of the discussion in the historical literature, focusing on the continued availability of certain waterpower sites, and the comparative costs of waterpower vs. steam, is of limited relevance (see e.g. Atack, 1979, and Atack et al 1980).
} 


\section{The main hypothesis: removing the locational constraint}

As already suggested, one of the key differences between water and steam power was of course the degree of flexibility in the choice of location. The use of water required that factories be located next to sufficiently copious streams having the "right" surrounding topography so that water wheels could be placed and provide the power requirements. However, it is clear that the optimal choice of location involves a variety of considerations other than the availability of appropriate streams, such as proximity to markets, transportation facilities (e.g. rail, ports), availability of labor, skills, capital, etc. The use of waterpower implied then a constraint on the effective geographic choice set, its stringency depending on the degree of coincidence between the availability of water and of the other factors. It follows that the replacement of water by steam meant at first the removal of such constraint, but in order to realize the benefits from the newly expanded choice set, firms had to engage in complementary activities: first and foremost their actual relocation, changes in the mix of inputs, in transport modes, etc. associated with the new locations, the (re)design of factories that would take advantage of the specific characteristics of the steam engine as prime mover (as opposed to waterwheels), etc.

We contend that the innovations that George Corliss introduced contributed greatly to tilting the balance away from waterpower and in favor of steam, particularly in the north Atlantic states. ${ }^{37}$ The adoption of steam meant the release of the geographical constraint, which allowed the optimal (re)location of factories, and the implementation of concomitant changes that were called for by the new locations and type of prime mover.

In so doing the Corliss engine fostered the growth of the big industrial urban centers, which characterized the closing decades of the $19^{\text {th }}$ century, thus contributing to and enabling the reaping of the benefits from agglomeration economies, which were in turn an important contributor to the growth of the economy. Of course, the feedback loop from agglomeration to further industrialization meant increased demand for steam engines, which in turn promoted further improvements in them. 
The interesting empirical questions then have to do with the way in which the historical contest between water and steam played out in the context of the intertwined processes of industrialization and urbanization. In particular, how can we ascertain the stringency of the locational constraint imposed by the reliance on waterpower? To what extent did each of the competing power modes foster or hinder urbanization? Notice that it is one thing to say that waterpower required a particular occurrence of topography and climate, and quite another to postulate that such occurrence was necessarily at odds with the location that would have been preferred otherwise by the using industries. In other words, the stringency of the locational constraint needs to be established empirically. Second, given the locations chosen by the industries using each type of power, they could have in principle attracted further population and industrial activity to the proximity of the manufacturing sites. In other words, it is an open question the extent to which the existing locations of water and steam at a point in time were propitious for further population and industrial growth, and hence for the generation of agglomeration economies around those locations.

We intend to address these questions by pivoting on the deployment of Corliss engines and of watermills in the Northeast as of $1870,{ }^{38}$ and looking forward and backwards in time: first, we estimate a location (or "adoption") equation of Corliss engines and of watermills as of 1870 (by county), as a function of population, physical and human capital and other variables from the 1850 census. Second, we estimate a model of population growth by county from 1870 onwards (up to 1900), as a function of the stock of Corliss engines, watermills, and control variables taken from the 1870 census. The "model" is thus as follows:

\footnotetext{
${ }^{37}$ Once again, west of the Appalachians water sources were much less abundant, and hence the direct cost advantages of steam were an overriding consideration. Thus, the closest contest between water and steam took place in the North and mid Atlantic states.

${ }^{38}$ As already mentioned, the data for watermills come from the 1880 census (there are no detailed data for 1870), whereas that for Corliss engines come from the 1869 petition, and hence the two sets of equations are not exactly aligned time wise. We proceed on the assumption that in the intervening decade (18701880) the distribution of watermills across counties within the North and Mid atlantic states change little . We know from Fenichel (1966) that the total HP of watermills in New England grew just by $17 \%$ during that decade (from 362 thousand in 1870 to 423 in 1880), and in the Middle Atlantic states it declined slightly (from 376 to 357); this in contrast with the rapid growth of steam, which more than doubled in those regions.
} 


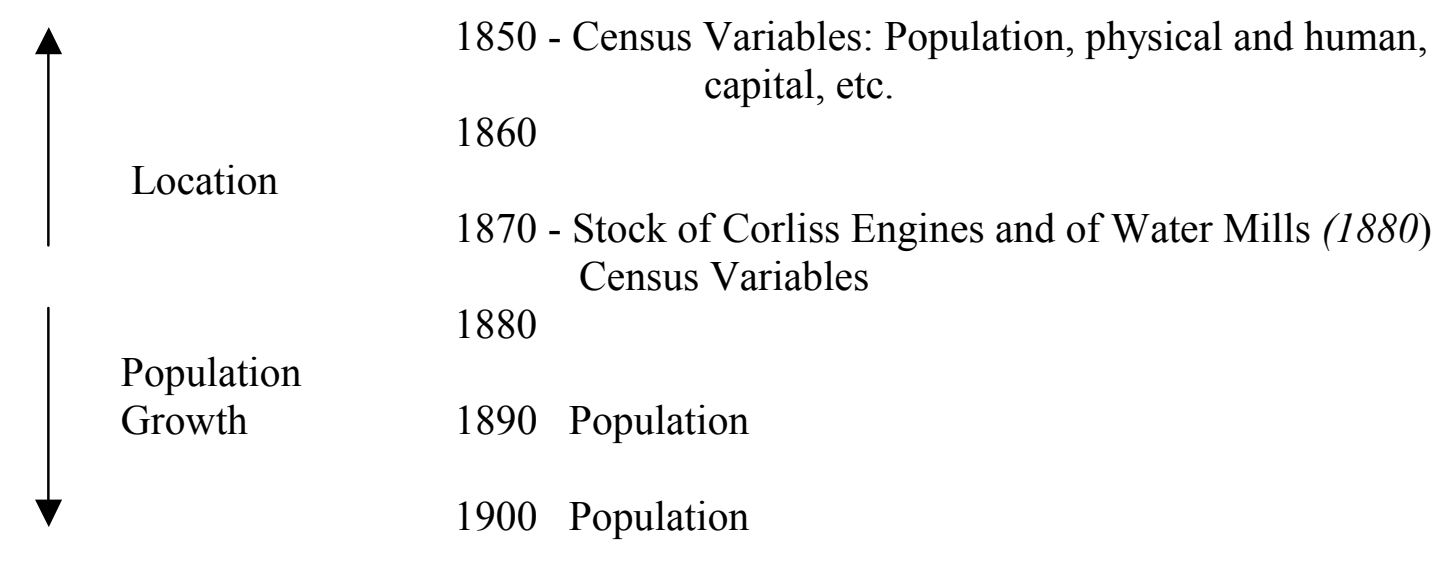

\section{The location of Corliss engines and of watermills}

We now turn to the issue of what determined the location of Corliss engines on the one hand, and of watermills on the other, in order to assess the stringency of the locational constraint imposed by the geographic requirements of waterpower. The leading hypothesis is that, freed of such constraints, the Corliss engine gravitated towards locations that already had clear advantages for industry, particularly for advanced, large-scale manufacturing, in terms of availability of inputs and skills, proximity to markets, etc. On the other hand, if indeed those constraints were binding, water-powered mills could not. We regard population size as the leading indicator for the existence of locational characteristics propitious for the development of advanced, large-scale industry: larger urban centers presumably offered a wider range of inputs and skills, constituted in and of themselves larger markets and had better access to wider markets due to the availability of transportation facilities, etc. Beyond population, we also use as regressors other indicators that may capture the availability of inputs and skills: ${ }^{39}$ capital invested in manufacturing, employment in manufacturing, the number of books in public libraries, and the number of public libraries, all of these in per capita terms.

We ran two sets of regressions: one having as the dependent variable the number of Corliss buyers by county as of 1870 , the other the number of watermills, each as a function 
of population, capital or employment in manufacturing per capita, books in public libraries per capita (all of these from the 1850 census), and state dummies. The distribution of Corliss buyers across counties is very skewed, with a large mass at zero:

\begin{tabular}{|c|c|c|}
\hline $\begin{array}{c}\text { Number of Corliss } \\
\text { buyers per county }\end{array}$ & $\begin{array}{c}\text { Number of } \\
\text { counties }\end{array}$ & \% of counties \\
\hline 0 & 200 & $82.6 \%$ \\
\hline 1 & 13 & $5.4 \%$ \\
\hline 2 & 11 & $4.6 \%$ \\
\hline 3 & 5 & $2.1 \%$ \\
\hline 4 & 3 & $1.2 \%$ \\
\hline $5-9$ & 3 & $1.2 \%$ \\
\hline $10-19$ & 3 & $1.2 \%$ \\
\hline $20+$ & 4 & $1.7 \%$ \\
\hline Total & 242 & $100.0 \%$ \\
\hline
\end{tabular}

The distribution of watermills is also skewed, with $25 \%$ of the counties having none. Both constitute typical count data, and hence OLS is not appropriate; thus, we use the Poisson and the Negative Binomial models to estimate both set of equations.

Table 4 shows the results for the various specifications (for completeness we also report the OLS). The key finding, highly significant and robust across all specifications, is that population strongly impacts the location of the Corliss, but not at all the geographic distribution of waterpower. That is, counties with larger populations attracted Corlissdriven plants, whereas population size had no impact whatsoever on the location of watermills. Similarly, counties that had by 1850 relatively more capital and/or more employment in manufacturing (per capita) also drew larger numbers of Corliss engines, as did counties with more books and/or more libraries. These effects are either not significant for watermills, or much smaller than for the Corliss. The contrast between Corliss engines and watermills in terms of the significance of these variables is sharper for the Negative Binomial than for the Poisson, quite likely because the latter suffers from overdispersion.

\footnotetext{
${ }^{39}$ Obviously, we were constrained in the choice of regressors by the set of variables available from the 1850 Census (see Appendix 3).
} 
For the sake of brevity we have suppressed in Table 4 the estimates for the state dummies; there is however one that is of interest, and that is the coefficient for Rhode Island, the hometown of Corliss. ${ }^{40}$ While positive, this coefficient is barely significant in most specifications for the Corliss equation; ${ }^{41}$ on the other hand, in quite a few of the watermills equations the Rhode Island dummy comes out negative, large and significant. Thus, the fact that Rhode Island attracted a relatively large number of Corliss engines and few watermills had to do more with that state apparently not being suitable for waterpower rather than to the fact that George Corliss was building engines there.

For the Corliss equation the right hand variables from the 1850 Census are clearly exogenous: Corliss began to build his steam engines in the late 1840s, and most of them were sold in the 1860s. For watermills that is not quite the case: presumably a large proportion of the watermills (unfortunately unknown to us) in operation at the time of the 1880 survey were already in place by 1850 . Thus, the waterpower equations may suffer from simultaneity bias, in that counties that for reasons unaccounted for in the model had attracted more watermills may have also drawn in a larger population, and perhaps also more physical and human capital. However, notice that endogeneity would in this case bias the estimates upwards, blunting the difference of the effect of the regressors on the Corliss versus watermills, that is, simultaneity biases would militate against our hypothesis. Thus, the real differences may be even more pronounced than what our results indicate, and hence the presence of endogeneity in the watermills equations can only strengthen the conclusions.

\section{Population growth from 1870 onwards}

The second part of the interplay between power modes and population looks forward in time, the question being: to what extent did the presence of Corliss engines on the one hand, and of watermills on the other, foster population growth across different locations? At first we estimate for that purpose simple OLS equations with the rate of

\footnotetext{
${ }^{40}$ The other consistent finding is the very large negative coefficient for Maine in the Corliss equations, for which we do not have a convincing rationale.

${ }^{41}$ It is large and significant only in the OLS equations, but these are the least plausible specifications; the base state is New York.
} 
post- 1870 population growth by county as the dependent variable, the number of Corliss buyers and of watermills as regressors, as well as a series of control variables from the 1870 Census, and state dummies. The results are shown in Table 5a: the population of counties with relatively many Corliss-driven establishments as of 1870 grew indeed faster in the following 2-3 decades, whereas counties with relatively many watermills grew at a slower pace. This key finding is both significant and very robust. ${ }^{42}$ The actual size of these effects is not very large, and yet it makes a difference over the long haul: the population of counties with one standard deviation more watermills than the average (133 versus 66) grew at an annual rate 2/10 of 1 percent slower; cumulated over $2-3$ decades that is a non trivial amount. At the upper tail the effect is very substantial: counties with at least 10 Corliss-driven establishments (there were 7 such counties) grew at an annual rate $0.5-1 \%$ higher than counties with none.

The industrial composition of watermills versus that of the Corliss may have had something to do with the differential impact on population growth: if we split the number of watermills per county into two groups, one consisting of the top four sectors where the Corliss was deployed (Textiles, Primary Metals, Non-manufacturing and Machinery, which accounted for $81 \%$ of the HP of Corliss engines), and another group with all the rest, the results are as follows: for watermills in those 4 sectors the coefficient is insignificant, whereas for the others it remains negative, significant and of similar size as in the original regressions with all watermills in there. That is, locations with watermills that mimicked the industrial composition of the Corliss at least did not experience a subsequent decline in their population, whereas counties with watermills in more traditional sectors did.

The estimates for the "controls" are also of interest. Previous population growth (either 1850-70 or 1860-70) is meant to capture underlying trends by county that just persist into the future, and hence constitutes an important overall proxy for more fundamental processes that are missing in the equation. The coefficients are large and

\footnotetext{
${ }^{42}$ The only qualification is that the inclusion of the 1870 population size as a regressor (to test for convergence) weakens the significance of the Corliss coefficient, but that is hardly surprising, given the
} 
highly significant in all specifications, suggesting that indeed there are underlying differences in the growth potential of counties that persist over the long run. The other controls constitute a snapshot of counties as of $1870:{ }^{43}$ Capital invested in manufacturing per establishment comes out positive and highly significant, i.e. counties with more capital-intensive industries attracted more population. This is an important control, in that the effect of the Corliss goes beyond that of just capital intensity. The effect of taxes is intuitively appealing: state taxes had a negative impact, but its size and significance obviously drops as we include state dummies; ${ }^{44}$ on the other hand county taxes seem to foster population growth, and the effect remains borderline significant in many specifications. We interpret county taxes as indicative of the provision of local public goods and hence having the potential to attract population, whereas higher state taxes represent, from the point of view of individual counties, just a higher burden that does not necessarily translate into more or better public goods. Last but not least, the $\mathrm{R}^{2} \mathrm{~s}$ are reassuringly large, implying that the effects captured in the model are first order in accounting for differential population growth over the long run.

There remains though the concern that the number of Corliss buyers per county may still suffer from endogeneity, in that some underlying long term phenomena not properly accounted for by the controls (even not by pre-1870 population growth) brought about both more adopters of Corliss steam engines prior to 1870, and faster population growth afterwards. We thus resort to IV estimation, using as instrument for the number of Corliss the predicted values from the "adoption" equations (see Table 4), i.e. from the count regressions of number of Corliss buyers per county on county variables as of 1850 . The time gap between these 1850 level variables and population growth post-1870 makes it more likely that the predicted values thus computed would be truly exogenous, and hence constitutes a legitimate instrument. Table $5 \mathrm{~b}$ presents the results, for different specifications (i.e. taking the predicted values from the negative binomial, the Poisson

high collinearity between the two.

${ }^{43}$ We tried many other such controls, including wages in manufacturing, different measures of wealth, etc. However, strong multicollinearity did not allow for precise estimation, and hence we had to make judgment calls as to which to include. 
and the LS equations, and using in some population growth for 1860-70 and in others for 1850-70). Reassuringly, the coefficient of Corliss buyers remains basically unchanged (vis a vis the OLS results in Table 5a), but its significance declines. ${ }^{45}$ Thus, even though we obtain a less precise estimate, it is quite clear that the effect is there and the result is robust: counties that adopted a larger number of Corliss engines exhibited faster growth in the following decades.

These results support then the hypothesized role of the Corliss in the dynamic interaction between industrialization and urbanization. Freed of the locational constraints of waterpower, manufacturing enterprises driven by steam engines could choose to locate "optimally", and hence were attracted to areas where, inter alia, they could take advantage of agglomeration economies. The presence of Corliss-driven manufacturers both contributed to these agglomeration effects, and probably also signaled that more was coming: Corliss engines were after all "trend setters" for industry, both in that they were deployed in advanced sectors, and in that they were typically of a larger scale. In time, locations with relatively many Corliss-driven establishments attracted further manufacturers and hence also fostered population growth. By contrast, watermills were no part of such positive loop: they located in sparsely populated areas to begin with, and failed to attract further economic activity and hence further population to those areas. In fact, the population in locations that had relatively many watermills actually declined (recall the negative sign of the coefficients for watermills in Tables $5 \mathrm{a}$ and $5 \mathrm{~b}$ ), gravitating instead towards the urban centers where steam took hold. To insist, this latter result is far from obvious: it was not a priori clear that the topographical requisites (and hence geographical constraints) of waterpower would also impair the clustering of industry and hence of urban centers in those sites.

It is interesting to note that many watermills had "auxiliary steam power", which was used both to add to capacity and to run the mills at times when waterpower was

\footnotetext{
${ }^{44}$ State taxes do vary across counties within states (since these are computed as per capita tax revenues), but nevertheless the variation within states is too small to allow for precise estimation, and hence we excluded this variable in all specifications where state dummies appear.
} 
unavailable due to weather conditions. The 1880 Census had data on auxiliary steam power just for 62 out of the 244 counties of the North and Mid Atlantic States; ${ }^{46}$ still, the total steam power reported there amounted to $64,965 \mathrm{HP}$, significantly more than the 46,339 HP of the Corliss engines listed in the Petition. Auxiliary steam power in the New England states alone amounted to $43,086 \mathrm{HP}$, which constituted $28 \%$ of the total steam power in the region, versus 27,797 HP of Corliss engines. Thus, waterpower did attract steam power, in what could have been the beginning of a positive loop (involving the further growth of population in those locations, etc.). However, this auxiliary steam power was just that, "auxiliary", and did not offset the decisive advantage that steam held by comparison with water, namely the freedom to locate optimally.

\section{Enabling Scale, and Rolling on...}

As already mentioned, Corliss engines were much more powerful than the vast majority of steam engines at the time, and similarly in comparison to water wheels. Table 6 shows the average HP of mills run with waterpower versus the average HP of users of Corliss engines: ${ }^{47}$ The scale of the latter was over 4 times larger on average than that of establishments relying on waterpower, and only in one sector, Pulp \& Paper, waterpowered mills were slightly larger than their counterpart Corliss users. Notice also that the average HP of Corliss users displays a large variance across sectors (at the extreme, the scale in Primary Metals is almost 9 times as large as in Printing). However, and as Table 1 reveals, there were very few Corliss users in the small-scale sectors (except for Machinery): each of the sectors with an average scale of less than $120 \mathrm{HP}$ account for no more that $1.7 \%$ of the total HP of Corliss engines, and then there is a big jump between the top of these small sectors (Furniture, with an average HP of 120), and the next one, Apparel with 228. In other words, $88 \%$ of the total HP of Corliss engines were deployed in sectors that averaged anywhere between 200 and 300 HP per establishment, which

\footnotetext{
${ }^{45}$ In particular, the t-values are lower when using as control 1850-70 (rather than 1860-70) population growth; it is not clear why that it so.

${ }^{46}$ We have not made use so far of these data because the coverage, as indicated, is not comprehensive, and we don't know what determined the reporting for some but not for other locations.

${ }^{47}$ Some of the mills operating water wheels had also auxiliary steam power and hence their average HP may be slightly understated, and likewise, some of the buyers of Corliss engines had also other types of engines in the same establishment.
} 
presumably meant at least $100 \mathrm{HP}$ per engine, some 5 times larger than the typical watermill or non-Corliss steam engine.

The large scale of establishments using Corliss engines in Metallurgy and in Textiles is consistent with other supporting evidence. ${ }^{48}$ Furthermore, it relates to one of the hypothesized mechanisms by which innovation complementarities played out in the case of the Corliss engine, further enhancing the GPT nature of steam engines. We conjecture that the introduction of the Corliss engine was an important factor enabling the setting up of large-scale factories, and hence the realization of scale economies in production and the advent of mass production, one of the distinctive features of industrialization in the closing decades of the $19^{\text {th }}$ century (see Chandler, 1977).

The fact that the Corliss may have played such an enabling role does not imply that waterpower suffered from inherent technological or topographical limitations that prevented it from running large-scale plants. True, watermills were on average of a much more modest scale than plants running on Corliss engines, and moreover, there were very few of truly large size: out of almost 16,000 mills that ran on water in 1880, only 90 deployed more than $500 \mathrm{HP}$ on average (just over one half of one percent), and an additional 859 mills had between 100 and 500 HP. Still, the fact that we do find some watermills even with 1,000 HP and more clearly means that there were no visible absolute constraints on scale for this power source. Moreover, what we see in the data is an equilibrium distribution of scale, both between water and steam, and within waterpower - obviously we do not know what would have been the scale of watermills had steam not taken its predominant place in the upper tail of HP.

As with many other instances whereby two technologies compete, we do not need to resort to the (clearly untenable) argument that waterpower had inherent scale limitations in order to assert the enabling role of Corliss engines: it is the conjunction of purely technological advantages and of other complementary economic factors that 
makes one technology play that role and not the other. We conjecture that freedom of location was, once again, the critical supporting factor: large-scale production required not just the technical ability to operate large plants, but also easy access to markets, both for inputs and for outputs. There were sites that could deliver large amounts of waterpower, but the fact is that too few were located near transportation hubs and population centers. Large-scale production may have been technologically and topographically feasible with waterpower, but not economically viable.

The booming textile industry of Fall River, Massachusetts, from the 1860s through the end of the $19^{\text {th }}$ century exemplifies the twin processes of relocation and realization of scale economies. The Corliss engine was hardly the only factor responsible for the development of Fall River, but it undoubtedly contributed to it a great deal (see Smith, 1944, pp. 45 and 47). ${ }^{49}$ Yonekawa (1987) discusses the factors underlying the burst in the formation of cotton spinning factories during the decades of 1870-1890, in vastly different locations: Oldham (England), Fall River (Massachusetts), and Bombay (India), and then also in Japan. Regarding Fall River, he writes:

"The invention by George Corliss in 1848 of a regulator allowing more accurate control of the power, and hence the speed, of the machinery was important in allowing the establishment of bigger and more powerful steam engines. This in turn led to larger mills, with 30,000 spindles not being uncommon." ... "The installation of large steam engines made it possible to build higher capacity mills, with some 37,000 spindles and 900 looms, such as Union Mills; organized in 1859, Union Mills was one of the earliest mills to utilize steam power on this scale." (Union Mills were located in Fall River)

However, it is the case of rolling mills, to which we now turn, that best captures the pivotal role of the Corliss, both in enabling scale per se, and in playing out the other technological advantages of the engine, particularly the ability to manage drastic fluctuations in power requirements.

\footnotetext{
${ }^{48}$ On metallurgy, see below the discussion on rolling mills; on textiles, we obtained information on the number of employees of 12 textile firms (out of the 60 that purchased Corliss engines): 10 of them had 1000 employees or more, one had 630, and one had between 250 and 500 employees.

${ }^{49}$ Steam provided just $25 \%$ of the power of textile mills in the US in 1870 and $44 \%$ in 1880 ; however, by 1875 steam had already accounted for $\mathbf{9 3 \%}$ of the power for textile mills in Fall River. Moreover, Smith (1944) notes that in 1875 there were 81 steam engines in operation in Fall River, generating 27,992 HP, which makes for an average of 345 HP per engine, certainly a large figure for the time.
} 


\section{Iron, steel, and rails: the role of the Corliss}

The operation of rolling mills, a key technology in the iron and steel industry as well as in other metallurgical industries, acquired by mid-century a critical place in the industrialization of America, particularly with the rapid expansion of the railroads. The Corliss engine came to play a pivotal role in the growth of rolling mills, both in that it allowed for a much larger scale of operations, and in that the engine's unique facility in responding to the specific (and, in the case of rolling mills, extreme) requirements of the industrial user, proved to be a decisive advantage. The enabling role of the Corliss for rolling mills, and through them its role in the building of railroads, constituted an important pathway along which innovational complementarities stemming from it played out.

The making of wrought iron in the first half of the nineteenth century had been reshaped by the technologies of puddling furnaces and rolling mills. Puddling allowed the introduction of mineral fuels in converting pig iron into wrought iron, and the introduction of rolling offered a mechanical substitute for hugely labor-intensive hammering at the forge in converting the wrought iron into certain desired shapes. By 1856 fully $95 \%$ of all wrought iron was made in rolling mills. ${ }^{50}$ As early as 1849 there were no less than 56 rolling mills in eastern Pennsylvania exploiting the rich anthracite deposits of the region, as well as 23 in western Pennsylvania. All but one of the western Pennsylvania rolling mills employed steam power by 1849 , whereas less than half in the eastern part of the state did so (Temin, 1964, p. 108).

The new metallurgical technologies enabled a huge expansion of the industry's raw material base and the attainment of higher productivity levels, but they usually led also to an expansion in the optimal scale of plant (the dependence of the earlier technology upon the use of charcoal had effectively imposed rigid upper limits to the size of plants). As the following table reveals, the overall trend toward larger scale was

\footnotetext{
${ }^{50}$ Temin, 1964, p. 101. Chapter 5 of Temin's book provides a useful overview of the economics of the rolling mill in the nineteenth century.
} 
persistent and was vastly intensified with the introduction of the Bessemer process, with its huge fixed cost requirements, shortly after the end of the Civil War:

\begin{tabular}{|c|c|c|c|}
\hline \multicolumn{4}{|c|}{$\begin{array}{c}\text { Average Size of Steel Works and Rolling Mills } \\
1869-1899\end{array}$} \\
\hline $\begin{array}{c}\text { Census } \\
\text { Year }\end{array}$ & $\begin{array}{c}\text { Capital } \\
\text { (thousand \$) }\end{array}$ & $\begin{array}{c}\text { Census-Year } \\
\text { Product (tons) }\end{array}$ & $\begin{array}{c}\text { No. of Wage } \\
\text { Earners }\end{array}$ \\
\hline 1869 & 156 & 3,000 & 119 \\
\hline 1879 & 267 & 7,000 & 220 \\
\hline 1889 & 661 & 14,000 & 332 \\
\hline 1899 & 967 & 23,000 & 412 \\
\hline \multicolumn{4}{|c|}{$\begin{array}{l}\text { Source: U.S. Census of Manufactures, 1914, Abstract, pp. 640- } \\
\text { 641; Appendix C, Table C.8. As reproduced in Temin, 1964, p. } \\
\text { 166. }\end{array}$} \\
\hline
\end{tabular}

Indeed the shift from iron to steel after the Civil War (by use of the Bessemer converter), and the construction of the nation's railway system, constituted one of the great transforming economic events of 19th century America. To cite only one narrow measure of the impact of this transition on the operation of the railroad system itself, steel rails had an expected life more than ten times as great as rails made of iron, which they replaced (Fishlow, 1966, p. 639). There is no doubt that the dramatic reduction in overland transportation costs associated with railroads was one of the critical factors that made the twin processes of industrialization and urbanization feasible, and the railroad rolling mills (rail mills) were a central part of this transformation. ${ }^{51}$

Although rolling mill practices had experienced considerable improvement before the introduction of Bessemer steel, the voracious demands of the railroads, post Bessemer, led to a great expansion of rolling mill output, along with a huge growth in the

\footnotetext{
${ }^{51}$ An important improvement in rail mill practice that came to distinguish American practice from that in Britain, was the invention of the three-high mill by John Fritz, at the Cambria Works, in 1857. "Within a few years these mills were common throughout the country. They saved time and labor, particularly in the manufacture of railway iron, by enabling the rails to be passed through the rolls in both directions, instead of passing in only one direction as in the two-high mills still used in England...The first American Bessemer rails produced commercially were rolled in 1867 by the Cambria Works. As steel rail manufacturing developed, special mills of a heavier type were designed to deal with the new metal." (V. Clark, 1929, II, p. 79).
} 
size of individual rolling mills. However, the technical problems involved in the enlargement of rolling mill capabilities were formidable. The rolling of iron and steel constituted one of the most difficult of industrial activities in terms of the demands that it imposed on steam engines. Back in 1838 the 26 rolling mills reported in the US had an average of 93 horsepower (Hunter, 1985, p. 83). By 1860, mills that rolled rails were already far larger than other rolling mills, and the largest of the rolling mills were steampowered. By 1870 railroad rolling mill engines as large as 600 horsepower were being utilized, but they required huge and costly gearing (Hunter, 1979, p. 438).

A key difficulty in rolling mills was that these huge engines were being called upon to make drastic and rapid alterations in the delivery of power. Speed in dealing with increasingly heavy loads was particularly urgent because red-hot ingots rapidly lose their malleability as they cool. The Corliss engine was especially well suited for these difficulties. It managed the fluctuations in power requirements far more successfully than other engines of the time. As noted by the operator of a copper rolling mill making first use of a Corliss engine, "Our power frequently varies from 60 to 360 horse power within a minute, without perceptibly affecting the speed of the engine" (Corliss, 1870, p. 26). Hunter, in a careful survey of engine performance of the period, concluded that "even under the extreme operating conditions characteristic of rolling mills, with their wide and abrupt fluctuations in load as the slabs or bars of metal entered and left the rolls, the Corliss engine performed extraordinarily well." (Hunter, 1985, p. 268)

It is difficult to visualize how waterpower could have been used to accommodate the concentration of mechanical power at the specific points of use, as was required, in the post-1870 iron and steel industry. The huge expansion in blast furnaces and rolling mills in the Bessemer age had simply reached a point where they exceeded the capacities of flowing water (Lesley, 1859). At rail mills in particular, horsepower requirements were far greater than in the rest of the iron and steel industry, and steam engine performance requirements were, as a consequence, far larger than elsewhere. Likewise, pre-Corliss steam engines could not cope with the sudden alterations in the delivery of power imposed by rolling mills - the key innovation of the Corliss, the automatic variable cut- 
off mechanism, is what freed the steam engine from this chocking constraint. On both accounts then, scope, and smoothness of operation under drastic fluctuations in power requirements, the Corliss engine played a critical enabling role for rolling mills, and hence for railroads.

\section{Further impact, in the US and abroad}

\subsection{The Corliss engine as dominant design in the US}

After the expiration of the Corliss patents in 1870, "Corliss" became the generic name for the vast majority of large stationary steam engines produced, sometimes with hyphenated names, to signify further improvements or modifications in the basic Corliss design. The industrial impact of this engine design was rapidly diffused, and the pervasiveness of Corliss' influence extended far beyond the output of his own firm or that of his licensees. A reference book published at the turn of the century (Shillitto, 1899) listed and described the wide proliferation of Corliss engines and their entry into numerous specialized uses. The descriptions include a large number of engines that usually acquired hyphenated names, combining "Corliss" with the name of later engine designers whose engines still incorporated the fundamental design innovations introduced by Corliss: Hamilton-Corliss Engine, Reynolds-Corliss Engine, ${ }^{52}$ Harris-Corliss Engine, Gordon's Improved Corliss Valve Gear, Eclipse-Corliss Engine, Columbian-Corliss Engine, Sioux-Corliss Engine, etc. Such was the reputation still attaching to the Corliss name even in the early years of the $20^{\text {th }}$ century, and more than 30 years after the expiration of the patents, that prominent business advertisements of firms producing heavy equipment continued to invoke the Corliss name (Corliss died in 1888, and his own firm ran rapidly downhill thereafter). ${ }^{53}$

\footnotetext{
${ }^{52}$ Edwin Reynolds was in some respects Corliss' successor. After working for Corliss for 16 years he left in 1877 and joined the E.P. Allis Company in Milwaukee. He was employed by that firm for about 25 years, as general superintendent and chief engineer, and devised some highly influential improvements in the Corliss valve gear. He was also responsible for designing and introducing the "heavy duty" engine that was widely adopted in rolling mills and mining operations (Hunter, 1985, pp. 299-300). This firm was later to become one of the most prominent manufacturers of machinery in the US under the name of the AllisChalmers Co.

53 A sample from 1903: "Allis-Chalmers Co., Chicago, Illinois, Sole Builders of Reynolds Corliss Engines;" "The Filer \& Stowell Company, Milwaukee, Wisconsin, Builders of Heavy-Duty Corliss Engines;" "The Bass Foundry \& Machine company, Fort Wayne, Indiana, Manufacturers of Corliss Engines;" "The Mesta Machine Company, Pittsburg, Pennsylvania, Corliss and Piston Valve Engines."
} 
A further piece of evidence of the pervasiveness of the Corliss design comes from a technical source: In 1903 James Tribe, author of a well-known handbook of instruction on the operation of compound steam engines, published a second edition of his handbook that, in the first edition, was simply called "Compound Engines." In the preface to the second edition he explained the switch to the new title, "Compound Corliss Engines:" "This volume...has virtually become a new book. A new name also seems to be appropriate, for since the nearest approach to perfect thermal efficiency is realized in the Corliss type of Engines, and the variable cut-off features embodied in the same are assumed in all the examples, it has become desirable to adopt the name "Compound Corliss Engines.” (Tribe, 1903).

Perhaps the most impressive evidence, from a single firm, of the enduring influence of the Corliss engine comes from the Mesta Machinery Company of Pittsburg. This firm was probably the most prominent producer of heavy steel mill machinery in the US at the turn of the century. In 1904 the company published a remarkably detailed, profusely illustrated catalog of its products, which could be purchased through its branch offices in New York, Chicago or Birmingham, Alabama. The catalog, which ran to well over one hundred pages, bore a title calling attention to its technological lineage: "Corliss and Piston-Valve Engines for Rolling Mills, Blast Furnaces and Power Plants." The catalog, which emphasizes its indebtedness to Corliss design and construction throughout, particularly emphasizes also the superiority of their engines and other heavyduty equipment in withstanding the intense physical punishment to which rolling mill equipment is subjected. ${ }^{54}$

\subsection{Impact in Europe}

The Corliss engine was much admired and experienced extensive sales in Europe, even at an early date. The British economic historian D.L. Burn, in a classic article,

\footnotetext{
${ }^{54}$ In the course of presenting its extensive descriptive material, the catalog also identified customers for specific machines, which were located primarily in western Pennsylvania, Ohio, Illinois and Alabama, and included such prominent names as the Carnegie Steel Company and the U.S. Steel Corporation.
} 
observed that the Corliss engine was first introduced into Britain in 1862 (Burn, 1931): "Within a few years it had established a reputation both for fuel economy and for uniformity of speed under a variable load ... By 1867 at least fifty Corliss engines had been manufactured here, three of them for Woolwich Arsenal and one for John Platt; and there were seven firms manufacturing them. One of these firms - Messrs. Hicks, Hargreaves \& Co. - is said to have produced 1,400 of these engines since that date." [p. 301] Burns adds in a footnote (4): "The Corliss engine was also made in Germany and Switzerland, and was made in England without English modifications by Galloway \& Co. It was adapted as a marine engine...In the United States it was made with standardized parts, which was not the practice with steam-engine manufacture in England. ${ }^{, 55}$

In the announcement of the award of the Rumford medal by the American Academy of Arts and Sciences to George Corliss, Scott Russell, the distinguished British engineer, was quoted as having stated that "several hundred" of Corliss" engines had been sold abroad (probably by 1867). Hunter states that Corliss engines were "widely taken up in Europe after its appearance and recognition at the Paris Exposition of 1867. Here an international jury awarded the highest competitive honor to the Corliss engine over a hundred other entries. At the Vienna Exhibition of 1873, although not represented by an engine, Corliss was given one of the highest awards available on the grounds (as stated by Robert Thurston) that "a large proportion of the steam-engines entered having been copied from his designs, he was really represented in every section of the Exhibition and by the engine-builders of every manufacturing nation." (Hunter, 1985, pp. 269-70). If this last accolade is not an exaggeration, it would suggest that the Corliss engine had by 1873 achieved the status of a dominant design in large parts of industrial Europe. ${ }^{56}$

\footnotetext{
${ }^{55}$ For an evaluation of American industrial technology by a highly sophisticated group of visiting British engineers in the first half of the 1850s, see the parliamentary reports reprinted in Nathan Rosenberg (ed.), The American System of Manufactures, Edinburgh University Press, 1968. The visiting group included Joseph Whitworth (1803-87). Whitworth was recognized not only as an engineer of remarkable talents, but also as the world's foremost manufacturer of machine tools.

${ }^{56} \mathrm{~A}$ few years later the French Societe industrielle de Mulhouse issued a report on the performance of a Corliss engine built in France and installed in a Schlumberger factory in Mulhouse (Walther-Meunier and Keller, 1878)
} 


\section{Concluding Remarks}

Even though the steam engine is widely regarded as the icon of the Industrial Revolution and a prime example of a "General Purpose Technology," its role in driving long-term growth is far from transparent. We have argued that the Corliss engine, embodying key innovations in performance as well as fuel efficiency, helped tip the balance in the fierce contest between steam and waterpower. In so doing, it helped propel the steam engine to a dominant position in the intertwined processes of industrialization and urbanization that characterized the growth of the US economy in the second half of the $19^{\text {th }}$ century. Indeed, the deployment of Corliss engines served as a catalyst for the massive relocation of industry away from rural areas and into large urban centers, thus fueling agglomeration economies, attracting further population, and fostering economic growth. This illustrates what we believe is an important aspect of the dynamics of GPTs, whether it is electricity in the early $20^{\text {th }}$ century or Information Technologies in the present era: the fact that they induce the massive relocation (and concomitant reorganization) of economic activity, which brings about widespread productivity gains and hence longterm growth. 


\section{References}

Allen, Z., The Science of Mechanics, Providence: Miller and Hammond, 1829.

The American Machinist, Power, Mechanical Engineering, Transactions of the ASME (various contemporary issues).

Atack, J., "Fact in Fiction? Relative Costs of Steam and Water Power: A Simulation Approach." Explorations in Economic History 16, 409-437,1979.

Atack, J., Bateman, F. and T. Weiss, "The Regional Diffusion and Adoption of the Steam Engine in American Manufacturing." The Journal of Economic History, 40(2), 281-308, 1980.

Bresnahan, T. and M. Trajtenberg, "General Purpose Technologies: Engines of Growth?" Journal of Econometrics, 65(1), pp. 83-108, 1995.

Burn, D. L., "The Genesis of American Engineering Competition, 1850-1870," Economic History Review, January 1931.

Chandler, A. D. The Visible Hand: The Managerial Revolution in American Business. Cambridge, MA, Belknap Press, 1977.

Chandler, A. D. "Anthracite Coal and the Beginnings of the Industrial Revolution in the United States," The Business History Review, Summer, 1972.

Clark, V. S., History of Manufactures in the United States: 1607-1860, Vol. II, New York, McGraw-Hill, 1929.

Corliss, G. H., In the Matter of the Petition of George H. Corliss for an Extension of His letters Patent for Improvements in Steam Engines. Providence: Providence Press Company, Printers, 1870.

The Corliss Papers collection at the John Hay Library, Brown University, Providence, RI.

David, P. A. (1991), "Computer and Dynamo: The Modern Productivity Paradox in a Not-Too-Distant Mirror." in Technology and Productivity: The Challenge for Economic Policy. Paris: OECD, pp. 315-347, 1991.

Du Boff, R. B., "The Introduction of Electrical Power in American Manufacturing", Economic History Review, December, 509-518, 1967.

Fenichel, A. H. "Growth and Diffusion of Power in Manufacturing 1839-1919." In Output, Employment and Productivity in the United States after 1800. National Bureau of 
Economic Research, Studies in Income and Wealth Vol. 30, 443-478. New York, Columbia University Press, 1966.

Fishlow A., "Productivity and Technological Change in the Railroad Sector, 1840-1910," in Output, Employment and Productivity in the United States after 1800, National Bureau of Economic Research, Studies in Income and Wealth, 30. New York, Columbia University Press, 1966.

Fogel, Robert W., Railroads and American Economic Growth: Essays in Econometric History. Baltimore, Md.: The John Hopkins Press, 1964.

Helpman, E. and M. Trajtenberg, "A Time to Sow and a Time to Reap: Growth Based on General Purpose Technologies." Helpman, E. (ed.) General Purpose Technologies and Economic Growth. Cambridge, MIT Press, 1998.

Helpman, E. General Purpose Technologies and Economic Growth. Cambridge, MIT Press, 1998.

Horwitz, M., The Transformation of American Law, 1780-1860, Cambridge MA: Harvard University Press, 1977.

Hunter, L. C. A History of Industrial Power in the US, 1780-1930, Vol I, Charlottesville: The University Press of Virginia, 1979.

Hunter, L. C. A History of Industrial Power in the United States, 1780-1930, Vol. II: Steam Power. Charlottesville: The University Press of Virginia, 1985.

Krugman, P. Geography and Trade. Mass and London: MIT Press. 1991.

Lesley J.P., The Iron Manufacturer's Guide to the Furnaces, Forges and Rolling Mills of the US, New York, J. Wiley, 1859.

Manuscript Collection on the Textile Industry at the Baker Library, Harvard Business School.

Rosenberg, N., "Technological Change in the Machine Tool Industry: 1840 - 1910. In: Perspectives on Technology. Cambridge: Cambridge University Press, 1976.

Rosenberg, N., "Technological Interdependence in the American Economy". In: Inside the Black Box: Technology and Economics. Cambridge: Cambridge University Press, 1982.

Rosenberg, Nathan, "Uncertainty and Technological Change". Landau, R., T. Taylor and G. Wright, The Mosaic of Economic Growth, Part V. Stanford University Press, Stanford, 1996. 
Shillitto, F.W. HandBook of Corliss Steam Engines (2d Edition). Bridgeport, Conn., 1899.

Sheldon, F. F., "Power and Speed in Cotton Mills," Proceedings of the 27th Annual Meeting of the Northeast Cotton Manufacturers' Association, Boston, 1892.

Smith, T. R., The Cotton Textile Industry of Fall River, Mass., King's Crown Press, 1944.

Sokoloff, K., "Inventive Activity in Early Industrial America: Evidence from Patent Records, 1790-1846.” Journal of Economic History, 48(4) 813-50, 1988.

Temin, P. Iron and Steel in Nineteenth Century America, an Economy Inquiry. Cambridge, MA: MIT Press, 1964.

Temin, P., "Steam and Waterpower in the Early Nineteenth Century," Journal of Economic History, June 1966.

Thurston, R. H., Stationary Steam Engines; especially as adapted to Electric Lighting Purposes, New York, 1884

Thurston, R. H. A History of the Growth of the Steam Engine. Ithaca, N.Y.: Cornell University Press, 1939.

Tribe, J. Compound Corliss Engines, Milwaukee, Wisconsin, 1903.

Trowbridge, W. P. Reports on the Water-power of the United States: Statistics of Power and Machinery Employed in Manufactures. $10^{\text {th }}$ U.S. Census, 1880.

U.S. Census Office, Department of Interior, Statistics of Power and Machinery Employed in Manufactures, Reports on the Water-Power of the United States, Part I. Washington, Government Printing Office, 1885.

U.S. Congress, House, Documents Relative to the Manufactures in the United States, collected by the Secretary of the Treasury, Louis McLane; Exec.Doc. No. 308, 22 ${ }^{\text {nd }}$ Cong., 1st sess., 1833.

U.S. Congress, House, Report on the Steam Engines in the United States, H. Doc. No. 21, $25^{\text {th }}$ Cong., 3 d sess., 1838.

von Tunzelmann, G. N., Steam Power and British Industrialization to 1860. Oxford: Oxford University Press, 1978.

Walther-Meunier, M. and Keller, M. G., Essai d'une machine Corliss construite par MM. Berger-Andre \& cie, a Thann, fonctionnant au tissage de MM. Schlumberger fils \& cie, a 
Mulhouse. Rapport presente a la Societe industrielle de Mulhouse, dans sa seance du 26 juin $1878,1878$.

Yonekawa, S. "Flotation Booms in the Cotton Industry, 1870-1890. A Comparative Study," Business History Review, Winter 551-81, 1987. 


\begin{tabular}{|c|c|c|c|c|c|c|}
\hline & & ample List & $\begin{array}{r}\text { Ap } \\
\text { f Bu }\end{array}$ & $\begin{array}{l}\text { oper } \\
\text { uye }\end{array}$ & $\begin{array}{l}\text { ndix } 1 \\
\text { rs of Corliss En }\end{array}$ & \\
\hline \# & Buyers & City & State & $\mathbf{H P}$ & Sector & Notes \\
\hline 1 & Sharp's Rifle Manufacturing & Hartford & $\mathrm{CT}$ & 250 & Firearms & City directory (1860-1870) \\
\hline 2 & William L. Wood & Hartford & CT & 30 & Wool & \\
\hline 3 & Edward Miller \& Co. & Meriden & CT & 150 & Wool & \\
\hline 4 & Foster, Merriam \& Co. & Meriden & CT & 50 & Hardware & Directory of N.E. Mfg 30a \\
\hline 5 & $\begin{array}{l}\text { Metropolitan } \\
\text { Washing Machine Co. }\end{array}$ & Middlefield & CT & 45 & Washing Machines & \\
\hline 6 & Russell Manufacturing & Middletown & CT & 100 & Webbing & $\begin{array}{l}\text { Dir. of N.E. Mfg 3a [Automoblile } \\
\text { Brake Linings] 59a [Webbing] }\end{array}$ \\
\hline 7 & L. Candee \& Co. & New Haven & CT & 455 & Rubber Goods & $\begin{array}{l}\text { Directory of N.E. Mfg. } 47 \mathrm{a} / \text { City } \\
\text { directory }\end{array}$ \\
\hline 8 & Cheney Brothers & So. Manchester & $\mathrm{CT}$ & 200 & Silk & $\begin{array}{l}\text { Directory of N.E. Mfg. 50a } \\
\text { (Silk Manufatures) }\end{array}$ \\
\hline 9 & Peck Smith Manufcaturing & Southington & CT & 85 & Manufacturing & \\
\hline 10 & $\begin{array}{l}\text { Mineral Springs } \\
\text { Manufacturing }\end{array}$ & Stafford Spring & CT & 60 & Mineral & \\
\hline 11 & W.C. Harding \& Co. & Stamford & CT & 100 & Wool & \\
\hline 12 & Meriden Malleable Iron & W. Merieden & CT & 35 & Iron Works & \\
\hline 13 & Shaw \& Knowles & New Castle & $\mathrm{DE}$ & 175 & NA & \\
\hline 14 & Giles, Bros. \& Co. & Chicago & IL & 125 & Watches and Jewelry & \\
\hline 15 & Sherman House & Chicago & IL & 20 & NA & \\
\hline 16 & Todd \& Richardson & Louisville & KY & 125 & NA & \\
\hline 17 & S. \& W. Foster & Attleboro & MA & 60 & NA & \\
\hline 18 & Assabet Manufacturing & Boston & MA & 150 & Manufacturing & City directory (1860-1870) \\
\hline 19 & Boston Elastic Fabric & Boston & MA & 250 & Textile & City directory (1860-1870) \\
\hline 20 & Charles E. Hall \& Co. & Boston & MA & 80 & Marble & City directory (1860-1870) \\
\hline 21 & Chickering \& Sons & Boston & MA & 120 & Musical Instruments & City directory (1860-1870) \\
\hline 22 & Dearborn, Robinson \& Co. & Boston & MA & 250 & Iron Works & City directory (1860-1870) \\
\hline
\end{tabular}




\section{Appendix 2}

Users of Corliss Engines Listed in Corliss' Petition (p.5 of the petition: motives for signing in, and beginning of list)

The following parties, users of my improvements, and representing the most important industrial interests of this country, join in asking the favorable consideration of my petition, upon the following invitation:

Providence, R. I.,

1870.

To

If the object of the enclosed Petition meets with your approval, please sign and return same to me, and oblige,

Yours, very respectfully,

GFORGE H. CORLISS.

To the Honorable Senate and House of Representatives, of the United States, in Congress assembled :

The andersigned, having been informed of the pendency of the petition of George H. Corlrss, of Providence, R. I., for an Fxtension of his Letrers Patent, for "Improvements in Steam Engines," and knowing by THE USE OF SAYD IMPROVEMENTS that they are of great practical value to the industrial interests of the country, and believing that he has not been adequately remunerated therefor, do join in an earnest request that his application may receive the favorable consideration of your Honorable body.

\begin{tabular}{|c|c|c|}
\hline NAMES. & PLACE OF BUSENESS. & $\begin{array}{c}\text { Borse } \\
\text { power } \\
\text { used. }\end{array}$ \\
\hline Androscoggin Mills. & Lewiston, Me. & 200 \\
\hline $\begin{array}{l}\text { Lewiston Machine Co } \\
\text { Manchester Print Wor }\end{array}$ & " " " & 50 \\
\hline $\begin{array}{l}\text { Manchester Print Work } \\
\text { Aretas Blood......... }\end{array}$ & $\underset{6}{\text { Manchester, N. F }}$ & $\begin{array}{r}450 \\
30\end{array}$ \\
\hline Eaton \& Ayer... & Nashua, & 125 \\
\hline Nashua Manufactur & 6 & 350 \\
\hline $\begin{array}{l}\text { D. H. Buffum. } \\
\text { C. M. Willard. }\end{array}$ & Great Falls "6 $\ldots \ldots \ldots$ & 25 \\
\hline $\begin{array}{l}\text { C. M. Willard. } \\
\text { S. A. Denio.. }\end{array}$ & $\begin{array}{l}\text { Castleton, Vt. . . . . . } \\
\text { Boston, Mass .......... }\end{array}$ & $\begin{array}{l}50 \\
60\end{array}$ \\
\hline E. H. Asher & "6 6" & 40 \\
\hline Lowell Felting Mills & ، & 40 \\
\hline Boston Elastic Fabric Co.. & “ $\ldots$ & 250 \\
\hline Charles E. Hall \& Co... & $\cdots$ & 80 \\
\hline
\end{tabular}




\section{Appendix 3}

\section{Sample Page from the Census' "Reports on Water-Power" for 1880}

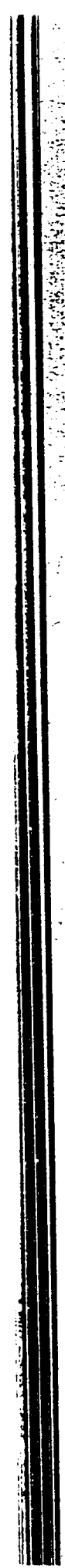

128 WATER-POWER OF THE UNITED STATES.

Table of utilized poicor on the Connecticut river and its tributaries-Continued.

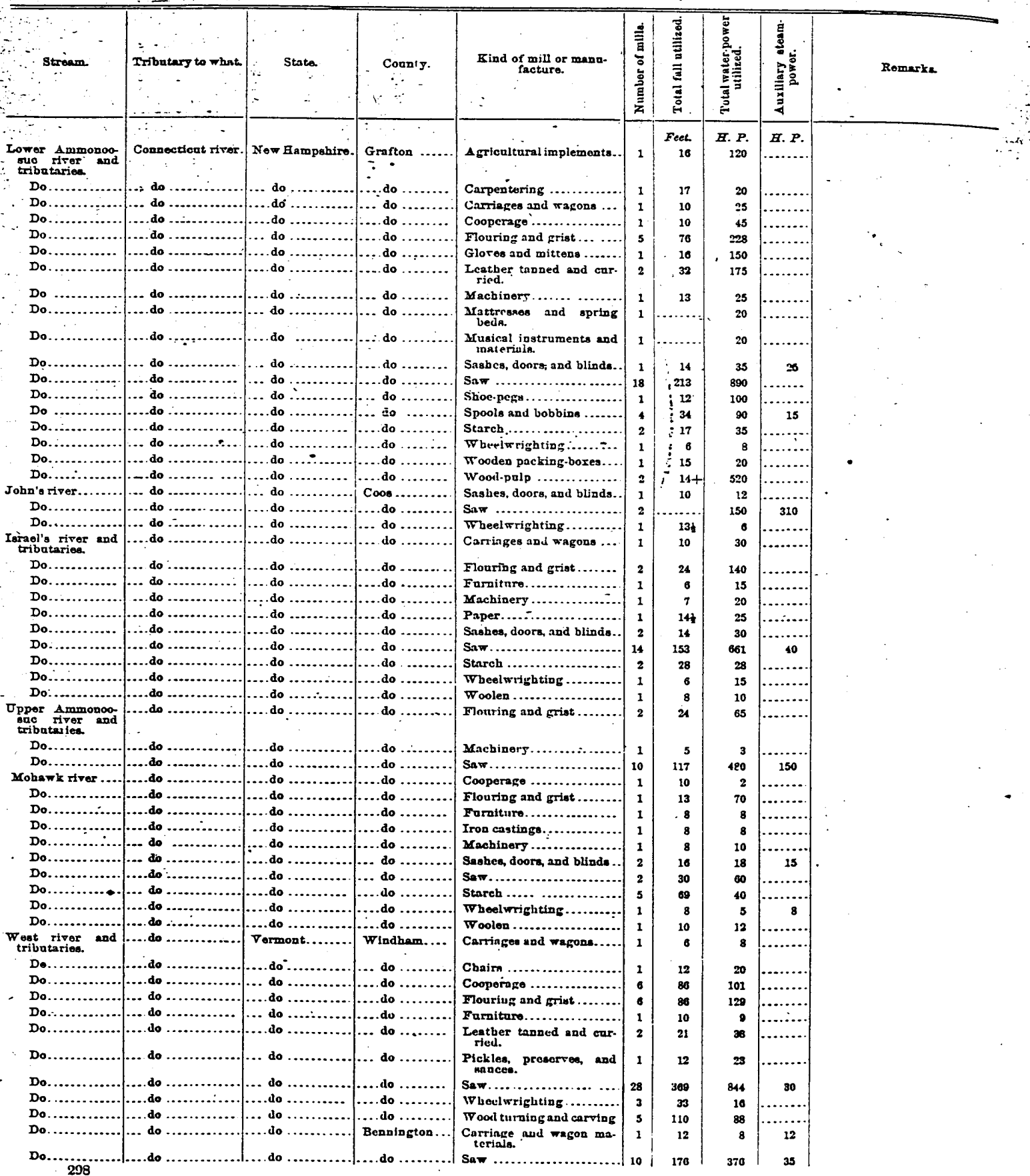




\section{Appendix 4}

\section{Demographic and Manufacturing Variables from the 1850 and 1870 Censuses, by County ${ }^{57}$}

\begin{tabular}{|l|l|}
\hline \multicolumn{2}{|l|}{ Variables from 1850 Census } \\
\hline TOTSLV50 & total number of slaves in 1850 \\
\hline Human Capital: & \\
\hline ADTLIT50 & aggregate number of adults who cannot read and write 1850 \\
\hline WHTLIT50 & total number of white adults who cannot read and write 1850 \\
\hline COLSTS50 & number of pupils in colleges 1850 \\
\hline LIBVOL50 & total number of volumes in public libraries 1850 \\
\hline PUBLIB50 & number of public libraries 1850 \\
\hline Manufacturing: & \\
\hline CAPINV50 & capital invested in manufacturing establishments 1850 \\
\hline EMPMAN50 & $\begin{array}{l}\text { number of persons employed in manufacturing establishments } \\
1850\end{array}$ \\
\hline VALPRD50 & value of annual product in manufacturing establishments 1850 \\
\hline Wealth & \\
\hline VCHRCH50 & total value of church property 1850 \\
\hline
\end{tabular}

\begin{tabular}{|l|l|}
\hline \multicolumn{2}{|l|}{ Variables from 1870 Census } \\
\hline Human Capital & \\
\hline ADNLIT70 & total number of persons who cannot read and write 1870 \\
\hline Manufacturing & \\
\hline CAPINV70 & total capital invested in dollars in manufacturing 1870 \\
\hline NBMANU70 & number of manufacturing establishments 1870 \\
\hline NBHNDS70 & total number of hands employed in manufacturing 1870 \\
\hline WAGES70 & total wages paid in manufacturing 1870 \\
\hline RAWMAT70 & value materials used in manufacturing 1870 \\
\hline VALPRD70 & value products manufacturing 1870 \\
\hline Wealth & \\
\hline ASSPRP70 & asserted valuation real and personal property 1870 \\
\hline TRUPRP70 & true valuation real and personal estate 1870 \\
\hline PRPVAL70 & value property all denominations \\
\hline Taxes & \\
\hline TAXCIT70 & total town city taxation 1870 \\
\hline TAXCT70 & total county taxation 1870 \\
\hline TXST70 & total state taxation 1870 \\
\hline TXSTLC70 & total non national taxation 1870 \\
\hline
\end{tabular}

\footnotetext{
${ }^{57}$ In addition, we have the population of each county for each of the census years 1850-1900, and the population of the localities (cities and towns) where buyers of Corliss engines were located.
} 
Appendix 5

Distribution of Buyers of Corliss Engines by Sub-Sector

\begin{tabular}{|c|c|c|c|c|}
\hline Sector and sub-sector & \begin{tabular}{|c|}
$\#$ of \\
Buyers
\end{tabular} & Total HP & \begin{tabular}{|c|} 
Average \\
HP
\end{tabular} & $\%$ of $\mathrm{HP}$ \\
\hline \multicolumn{5}{|l|}{ Apparel } \\
\hline Clothing & 5 & 1320 & 264 & $2.81 \%$ \\
\hline Hats & 1 & 50 & 50 & $0.11 \%$ \\
\hline \multicolumn{5}{|c|}{ Chemical and allied products } \\
\hline Paints & 3 & 190 & 63 & $0.40 \%$ \\
\hline \multicolumn{5}{|c|}{ Fabricated metal products } \\
\hline Pipes & 1 & 30 & 30 & $0.06 \%$ \\
\hline Sterling Silver and Plated Ware & 1 & 80 & 80 & $0.17 \%$ \\
\hline Wire and Cable & 3 & 1355 & 452 & $2.89 \%$ \\
\hline \multicolumn{5}{|c|}{ Food and kindred products } \\
\hline Flour & 3 & 850 & 283 & $1.81 \%$ \\
\hline \multicolumn{5}{|c|}{ Furniture and fixtures } \\
\hline Carpets and Rugs & 1 & 180 & 180 & $0.38 \%$ \\
\hline Hangings & 1 & 60 & 60 & $0.13 \%$ \\
\hline \multicolumn{5}{|c|}{ Leather and leather products } \\
\hline Leather & 1 & 40 & 40 & $0.09 \%$ \\
\hline \multicolumn{5}{|c|}{ Lumber and wood products } \\
\hline Carpenters & 3 & 225 & 75 & $0.48 \%$ \\
\hline Wood & 4 & 345 & 86 & $0.74 \%$ \\
\hline \multicolumn{5}{|c|}{ Machinery } \\
\hline Firearms & 3 & 340 & 113 & $0.72 \%$ \\
\hline Hardware & 2 & 115 & 58 & $0.25 \%$ \\
\hline Machines & 2 & 75 & 38 & $0.16 \%$ \\
\hline Screw Machine Products & 1 & 25 & 25 & $0.05 \%$ \\
\hline Sewing Machines & 1 & 450 & 450 & $0.96 \%$ \\
\hline Steam (Corliss) Engines & 4 & 210 & 53 & $0.45 \%$ \\
\hline Stoves & 2 & 80 & 40 & $0.17 \%$ \\
\hline Textile Machinery & 3 & 120 & 40 & $0.26 \%$ \\
\hline Tools & 4 & 295 & 74 & $0.63 \%$ \\
\hline Washing Machines & 1 & 45 & 45 & $0.10 \%$ \\
\hline Watches and Jewelry & 2 & 165 & 83 & $0.35 \%$ \\
\hline \multicolumn{5}{|c|}{ Nonmanufacturing } \\
\hline Dealers & 1 & 60 & 60 & $0.13 \%$ \\
\hline Hotel Owners & 2 & 60 & 30 & $0.13 \%$ \\
\hline Imports & 1 & 300 & 300 & $0.64 \%$ \\
\hline Lunatic Asylum & 1 & 15 & 15 & $0.03 \%$ \\
\hline Merchants & 5 & 1640 & 328 & $3.49 \%$ \\
\hline
\end{tabular}




\begin{tabular}{|c|c|c|c|c|}
\hline \multicolumn{5}{|c|}{ Primary metal industries } \\
\hline Copper & 2 & 470 & 235 & $1.00 \%$ \\
\hline Foundry & 2 & 100 & 50 & $0.21 \%$ \\
\hline Iron Works & 13 & 4820 & 371 & $10.27 \%$ \\
\hline Metal Works & 2 & 1110 & 555 & $2.37 \%$ \\
\hline Mineral & 1 & 60 & 60 & $0.13 \%$ \\
\hline \multicolumn{5}{|c|}{ Printing, publishing and allied products } \\
\hline Press and Printing & 6 & 225 & 38 & $0.48 \%$ \\
\hline \multicolumn{5}{|c|}{ Professional instruments, miscellaneous } \\
\hline Instruments & 1 & 40 & 40 & $0.09 \%$ \\
\hline Musical Instruments & 1 & 120 & 120 & $0.26 \%$ \\
\hline \multicolumn{5}{|c|}{ Pulp, paper and allied products } \\
\hline Paper and Pulp & 3 & 355 & 118 & $0.76 \%$ \\
\hline \multicolumn{5}{|c|}{ Rubber products } \\
\hline Rubber Goods & 3 & 785 & 262 & $1.67 \%$ \\
\hline \multicolumn{5}{|c|}{ Stone, clay and glass products } \\
\hline Bricks & 1 & 30 & 30 & $0.06 \%$ \\
\hline Marble & 1 & 80 & 80 & $0.17 \%$ \\
\hline \multicolumn{5}{|c|}{ Textile mill products } \\
\hline Bleaching and dyeing & 3 & 1325 & 442 & $2.82 \%$ \\
\hline Cordage & 5 & 1650 & 330 & $3.52 \%$ \\
\hline Cotton and Wool & 4 & 2005 & 501 & $4.27 \%$ \\
\hline Cotton Fabric and Goods & 24 & 8737 & 364 & $18.62 \%$ \\
\hline Print Works & 4 & 840 & 210 & $1.79 \%$ \\
\hline Silk & 1 & 200 & 200 & $0.43 \%$ \\
\hline Tape & 1 & 15 & 15 & $0.03 \%$ \\
\hline Textile & 5 & 590 & 118 & $1.26 \%$ \\
\hline Webbing & 1 & 100 & 100 & $0.21 \%$ \\
\hline Wool & 12 & 1620 & 135 & $3.45 \%$ \\
\hline \multicolumn{5}{|c|}{ Transportation equipment } \\
\hline Locomotive Works & 5 & 240 & 48 & $0.51 \%$ \\
\hline \multicolumn{5}{|c|}{ Unknown type of manufacturing } \\
\hline "Manufacturing" & 21 & 2420 & 115 & $5.16 \%$ \\
\hline "Mills" & 8 & 2230 & 279 & $4.75 \%$ \\
\hline Classification not available & 65 & 8047 & 124 & $17.15 \%$ \\
\hline Total & 257 & 46934 & 183 & $100.00 \%$ \\
\hline
\end{tabular}




\begin{tabular}{|c|c|c|c|c|c|c|}
\hline \multicolumn{7}{|c|}{$\begin{array}{c}\text { Appendix } 6 \\
\text { Distribution of Corliss Buyers by Cities } \\
\text { (sorted by } H P \text { ) } \\
\end{array}$} \\
\hline & City & State & \begin{tabular}{|} 
Population \\
1860
\end{tabular} & Buyers & HP & Avg. HP \\
\hline 1 & Providence & RI & 50666 & 34 & 8140 & 239 \\
\hline 2 & Philadelphia & PA & 565529 & 19 & 4505 & 237 \\
\hline 3 & Boston & MA & 202917 & 19 & 2990 & 157 \\
\hline 4 & Pittsburgh & PA & 49217 & 4 & 2615 & 654 \\
\hline 5 & New York & $\mathrm{NY}$ & 805658 & 20 & 2255 & 113 \\
\hline 6 & New Bedford & MA & 22300 & 3 & 2250 & 750 \\
\hline 7 & Chester & PA & 4631 & 26 & 1935 & 74 \\
\hline 8 & Lawrence & MA & 17639 & 4 & 1520 & 380 \\
\hline 9 & Fall River & MA & 14026 & 4 & 1375 & 344 \\
\hline 10 & Troy & NY & 39235 & 1 & 1340 & 1340 \\
\hline 11 & Utica & NY & 22529 & 4 & 1195 & 299 \\
\hline 12 & Pawtucket & RI & 4200 & 5 & 1005 & 201 \\
\hline 13 & Waltham & MA & 6397 & 3 & 990 & 330 \\
\hline 14 & Taunton & MA & 15376 & 7 & 755 & 108 \\
\hline 15 & Manayunk & PA & & 2 & 680 & 340 \\
\hline 16 & Bristol & RI & 5271 & 2 & 670 & 335 \\
\hline 17 & Worcester & MA & 24960 & 4 & 665 & 166 \\
\hline 18 & Gloucester & $\mathrm{NJ}$ & & 1 & 610 & 610 \\
\hline 19 & Frankford & $\mathrm{PA}$ & 207 & 2 & 500 & 250 \\
\hline 20 & Manchester & $\mathrm{NH}$ & 20107 & 2 & 480 & 240 \\
\hline 21 & Nashua & $\mathrm{NH}$ & 10065 & 2 & 475 & 238 \\
\hline 22 & New Haven & $\mathrm{CT}$ & 39262 & 1 & 455 & 455 \\
\hline 23 & Squabetty & MA & & 1 & 450 & 450 \\
\hline 24 & Newburyport & MA & 13401 & 3 & 410 & 137 \\
\hline 25 & Chicopee & MA & 7261 & 1 & 400 & 400 \\
\hline 26 & Newburgh & NY & 15196 & 1 & 350 & 350 \\
\hline 27 & Paterson & NJ & 19586 & 3 & 325 & 108 \\
\hline 28 & Malden & MA & 5865 & 1 & 300 & 300 \\
\hline 29 & Westerly & RI & 3470 & 2 & 300 & 150 \\
\hline 30 & E. Greenwich & RI & 2882 & 2 & 285 & 143 \\
\hline 31 & Hartford & CT & 29152 & 2 & 280 & 140 \\
\hline 32 & Syracuse & NY & 28119 & 2 & 280 & 140 \\
\hline 33 & Alleghany City & PA & 28702 & 1 & 250 & 250 \\
\hline 34 & Lewiston & $\mathrm{ME}$ & 7424 & 2 & 250 & 125 \\
\hline 35 & St. Louis & $\mathrm{MO}$ & 160773 & 1 & 250 & 250 \\
\hline 36 & W. Wareham & MA & 3186 & 1 & 250 & 250 \\
\hline 37 & Conshohoken & PA & 1741 & 2 & 230 & 115 \\
\hline 38 & Watertown & MA & 3270 & 1 & 215 & 215 \\
\hline 39 & Clinton & MA & 3859 & 2 & 210 & 105 \\
\hline 40 & Baltimore & MD & 212418 & 1 & 200 & 200 \\
\hline 41 & Meriden & CT & 7426 & 2 & 200 & 100 \\
\hline 42 & So. Manchester & $\mathrm{CT}$ & 3924 & 1 & 200 & 200 \\
\hline
\end{tabular}




\begin{tabular}{|c|c|c|c|c|c|c|}
\hline 43 & Canton & MA & 3242 & 3 & 197 & 66 \\
\hline 44 & Lynn & MA & 19083 & 2 & 185 & 93 \\
\hline 45 & Newport & $\mathrm{RI}$ & 10508 & 2 & 180 & 90 \\
\hline 46 & New Castle & $\mathrm{DE}$ & 3468 & 1 & 175 & 175 \\
\hline 47 & Sherburne & NY & 2701 & 2 & 167 & 84 \\
\hline 48 & River Point & $\mathrm{RI}$ & & 2 & 165 & 83 \\
\hline 49 & Salem & MA & 22252 & 2 & 160 & 80 \\
\hline 50 & Hingham & MA & 4351 & 1 & 150 & 150 \\
\hline 51 & Montgomery Co. & PA & & 1 & 150 & 150 \\
\hline 52 & Chicago & IL & 109260 & 2 & 145 & 73 \\
\hline 53 & Non-available & - & & 1 & 130 & 130 \\
\hline 54 & Gardner & MA & 2646 & 1 & 125 & 125 \\
\hline 55 & Louisville & KY & 68033 & 1 & 125 & 125 \\
\hline 56 & New Brunswick & NJ & 11256 & 1 & 120 & 120 \\
\hline 57 & Huntington & MA & 1216 & 1 & 100 & 100 \\
\hline 58 & Middletown & CT & & 1 & 100 & 100 \\
\hline 59 & Stamford & $\mathrm{CT}$ & 7185 & 1 & 100 & 100 \\
\hline 60 & Brooklyn & NY & 2666661 & 2 & 90 & 45 \\
\hline 61 & Easton & $\mathrm{PA}$ & 8944 & 1 & 90 & 90 \\
\hline 62 & Southington & $\mathrm{CT}$ & 3315 & 1 & 85 & 85 \\
\hline 63 & Uxbridge & MA & 3133 & 2 & 85 & 43 \\
\hline 64 & Trenton & $\mathrm{NJ}$ & 17228 & 2 & 80 & 40 \\
\hline 65 & Lambertville & $\mathrm{NJ}$ & 2699 & 1 & 75 & 75 \\
\hline 66 & Attleboro & MA & 1387 & 1 & 60 & 60 \\
\hline $67 \mid$ & East Cambridge & MA & 26060 & 1 & 60 & 60 \\
\hline 68 & No. Dighton & MA & 1733 & 1 & 60 & 60 \\
\hline 69 & South Easton & MA & 779 & 1 & 60 & 60 \\
\hline 70 & Stafford Spring & $\mathrm{CT}$ & 3397 & 1 & 60 & 60 \\
\hline 71 & W. Roxbury & MA & & 1 & 60 & 60 \\
\hline 72 & Castleton & VT & 2852 & 1 & 50 & 50 \\
\hline 73 & Hohokus & NJ & 2352 & 1 & 50 & 50 \\
\hline 74 & Norwich & NY & 4356 & 1 & 50 & 50 \\
\hline 75 & Plymouth & MA & 6276 & 1 & 50 & 50 \\
\hline 76 & Woonsocket & RI & 21564 & 1 & 50 & 50 \\
\hline 77 & Middlefield & $\mathrm{CT}$ & 8620 & 1 & 45 & 45 \\
\hline 78 & Springfield & MA & 15199 & 1 & 40 & 40 \\
\hline 79 & Woburn & MA & 6287 & 1 & 40 & 40 \\
\hline 80 & Germantown & PA & 2320 & 1 & 35 & 35 \\
\hline 81 & W. Merieden & $\mathrm{CT}$ & & 1 & 35 & 35 \\
\hline $82 \mathrm{H}$ & alls of the Schuylkill & PA & 4864 & 1 & 25 & 25 \\
\hline 83 & Great Falls & $\mathrm{NH}$ & & 1 & 25 & 25 \\
\hline 84 & Fort Palin & NY & & 1 & 20 & 20 \\
\hline 85 & Leicester & MA & 2748 & 1 & 15 & 15 \\
\hline 86 & Montrose & PA & & 1 & 15 & 15 \\
\hline 87 & Marlboro & MA & 5911 & 1 & 10 & 10 \\
\hline & Total & & $42,156^{*}$ & 257 & 46,934 & 183 \\
\hline
\end{tabular}

*Average population per city 


\section{Appendix 7 \\ Estimates of Steam and Water Horsepower (HP) prior to 1870}

\section{Estimates for the USA}

Table A7.1

\begin{tabular}{|l|c|c|c|c|c|c|}
\hline & \multicolumn{2}{|c|}{$\begin{array}{c}\text { \# of prime movers } \\
\text { (Atack, 1979) }\end{array}$} & \multicolumn{2}{c|}{ Steam hp } & \multicolumn{2}{c|}{ Water hp } \\
\hline & $\begin{array}{c}(1) \\
\text { steam } \\
\text { engines in } \\
\text { use }\end{array}$ & $\begin{array}{c}(2) \\
\text { waterwheels } \\
\text { and turbines in } \\
\text { use }\end{array}$ & $\begin{array}{c}(3) \\
\text { Steam hp } \\
\text { (Fenichel, } \\
1966)\end{array}$ & $\begin{array}{c}\text { (4) } \\
\text { Average } \\
\text { hp per } \\
\text { engine }\end{array}$ & $\begin{array}{c}\text { (5) } \\
\text { Water hp } \\
\text { (Fenichel, } \\
1966)\end{array}$ & $\begin{array}{c}\text { Average hp } \\
\text { per water } \\
\text { wheel }\end{array}$ \\
\hline $\mathbf{1 8 3 8}$ & 1,420 & $\mathbf{2 9 , 3 2 4}$ & 36.1 & 25.4 & $\mathbf{6 4 4}$ & $\mathbf{2 2 . 0}$ \\
\hline $\mathbf{1 8 5 0}$ & 8,598 & 37,602 & $\mathbf{2 3 0}$ & $\mathbf{2 6 . 8}$ & $\mathbf{8 2 7}$ & $\mathbf{2 2 . 0}$ \\
\hline $\mathbf{1 8 6 0}$ & 25,577 & 46,260 & $\mathbf{7 2 4}$ & $\mathbf{2 8 . 3}$ & $\mathbf{1 , 0 1 8}$ & $\mathbf{2 2 . 0}$ \\
\hline $\mathbf{1 8 7 0}$ & 40,191 & 51,018 & 1,215 & 30.2 & 1,131 & 22.2 \\
\hline $\mathbf{1 8 8 0}$ & 56,123 & 55,404 & 2,186 & 39.0 & 1,227 & 22.1 \\
\hline In bold: estimates & & & & & \\
\hline
\end{tabular}

Steam: First, we computed the average hp per engine for 1838 and 1870 (column 4), dividing the figures in column (3) by those in column (1). We then interpolated the average hp for 1850 and 1860 as follows: we computed the actual rate of growth of average hp from 1838 to 1870 , assumed a constant annual rate of growth throughout the period, and computed on that basis the (estimated) average hp for 1850 and 1860. We then multiplied these averages by the number of engines for those years, thus obtaining the bold figures in column (3).

Water: The procedure was similar to that for steam, except that we did not have data for 1838 and hence could not interpolate. However, the average hp per waterwheel remained constant between 1870 and 1880 (at about $22 \mathrm{hp}$ ) and hence we assumed that this same average holds for 1850 and 1860. We then multiplied $22 \mathrm{hp}$ by the number of waterwheels in those years, to obtain the total water hp for 1850 and 1860 . As to 1838 : we computed the average annual rate of growth of the number of waterwheels between 
1850 and $1860,{ }^{58}$ assumed that this same rate of growth applied between 1838 and 1850 for total $\mathrm{hp}$, and thus extrapolated for 1838: $827 /\left((1.02)^{* * 12}\right)=644$.

\section{Estimates for New England (NE)}

\section{Table A7.2}

\begin{tabular}{|l|c|c|c|c|c|}
\hline & $\begin{array}{c}(1) \\
\text { \# of steam } \\
\text { engines in NE } \\
\text { (Atack } \text { et al, } \\
1980 \text { ) }\end{array}$ & $\begin{array}{c}\text { Steam hp } \\
\text { in NE } \\
\text { (Fenichel, } \\
1966)\end{array}$ & $\begin{array}{c}(3) \\
\text { Average } \\
\text { hp per } \\
\text { engine }\end{array}$ & $\begin{array}{c}\text { (4) } \\
\text { Water hp } \\
\text { total USA } \\
\text { (from Table } \\
\text { A7.1, col. 5) }\end{array}$ & $\begin{array}{c}\text { Water hp } \\
\text { in NE: } \\
32 \% \text { of (4) }\end{array}$ \\
\hline 1838 & 319 & 4.9 & 25.4 & 644 & $\mathbf{2 0 6}$ \\
\hline 1850 & 1,271 & $\mathbf{3 4 . 1}$ & $\mathbf{2 6 . 8}$ & 827 & $\mathbf{2 6 5}$ \\
\hline 1860 & 3,978 & $\mathbf{1 1 2 . 6}$ & $\mathbf{2 8 . 3}$ & 1,018 & $\mathbf{3 2 6}$ \\
\hline
\end{tabular}

The estimates for steam were computed in the same manner as for the whole USA, i.e. we took the average hp per engine from table A7.1, and multiplied them by the number of engines in NE for 1850 and 1860. Since we did not have the number of waterwheels by region, the estimates for water hp were computed as follows: In 1870 New England accounted for $32 \%$ of all water hp in the USA; we simply assumed that this same percentage held for the earlier years, and hence obtained column (5) simply by multiplying 0.32 times the estimates of total water hp from column (4) (which in turn are the estimates from Table A7.1). Clearly, these estimates of water hp in NE are more questionable than those for steam, and should be taken as just ballpark "guesstimates."

As to the estimates for the USA exclusive of New England, we just took the difference.

\section{Sources:}

Fenichel, (1966), Atack (1979), Atack et al. (1980),

\footnotetext{
${ }^{58}$ That is, $\left.46,260 / 37,602\right)^{* *}(1 / 10)-1=0.02$.
} 


\begin{tabular}{|l|c|c|c|c|}
\hline \multicolumn{5}{|c|}{$\begin{array}{c}\text { Table 1 } \\
\text { Distribution of Buyers of Corliss Engines, by Main Sector } \\
\text { sorted by total HP) }\end{array}$} \\
\hline Sector & $\begin{array}{c}\text { \# of } \\
\text { Buyers }\end{array}$ & $\begin{array}{c}\text { Total } \\
\text { HP }\end{array}$ & $\begin{array}{c}\text { \% of } \\
\text { Total } \\
\text { HP* }\end{array}$ & $\begin{array}{c}\text { Average } \\
\text { HP }\end{array}$ \\
\hline Textile mill products & 60 & 17082 & 49.9 & 285 \\
\hline Primary metal industries & 20 & 6560 & 19.2 & 328 \\
\hline Non-manufacturing & 10 & 2060 & 6.0 & 206 \\
\hline Machinery & 25 & 1920 & 5.6 & 77 \\
\hline Fabricated metal products & 5 & 1465 & 4.3 & 293 \\
\hline Apparel & 6 & 1370 & 4.0 & 228 \\
\hline Food and kindred products & 3 & 850 & 2.5 & 283 \\
\hline Rubber products & 3 & 785 & 2.3 & 262 \\
\hline Lumber and wood products & 7 & 570 & 1.7 & 81 \\
\hline Pulp, paper and allied products & 3 & 355 & 1.0 & 118 \\
\hline Furniture and fixtures & 2 & 240 & 0.7 & 120 \\
\hline Transportation equipment & 5 & 240 & 0.7 & 48 \\
\hline $\begin{array}{l}\text { Printing, publishing and allied } \\
\text { products }\end{array}$ & 6 & 225 & 0.7 & 38 \\
\hline Chemicals and allied products & 3 & 190 & 0.6 & 63 \\
\hline $\begin{array}{l}\text { Professional instruments, } \\
\text { miscellaneous }\end{array}$ & 2 & 160 & 0.5 & 80 \\
\hline Stone, clay and glass products & 2 & 110 & 0.3 & 55 \\
\hline Leather and leather products & 1 & 40 & 0.1 & 40 \\
\hline Sub-Total for assigned buyers & $\mathbf{1 6 3}$ & $\mathbf{3 4 2 2 2}$ & $\mathbf{1 0 0 . 0}$ & $\mathbf{2 1 0}$ \\
\hline Unknown type of manufacturing & 29 & 4650 & 9.9 & 160 \\
\hline Classification unknown & 65 & 8062 & 17.2 & 124 \\
\hline Sub-Total for not assigned & $\mathbf{9 4}$ & $\mathbf{1 2 7 1 2}$ & $\mathbf{2 7 . 1}$ & $\mathbf{1 3 5}$ \\
\hline Grand Total & $\mathbf{2 5 7}$ & $\mathbf{4 6 9 3 4}$ & $\mathbf{1 0 0 . 0}$ & $\mathbf{1 8 3}$ \\
\hline & & & & \\
\hline & & & & \\
\hline & & & & \\
\hline
\end{tabular}

* For the buyers classified into sectors, this is the percentage out of the (sub) total HP for assigned buyers (34222 HP); these buyers constitute $73 \%$ of the total HP. 


\begin{tabular}{|c|c|c|c|c|}
\hline \multicolumn{5}{|c|}{$\begin{array}{c}\text { Table } 2 \\
\text { Distribution of Corliss Engines, Water Power, } \\
\text { and Steam Power, }{ }^{*} \text { by sector, } 1870 \\
\text { (sorted by column } 4 \text { ) }\end{array}$} \\
\hline Sector & $\begin{array}{c}\text { (1) } \\
\text { Corliss } \\
\text { Engines } \\
\% \text { of total }\end{array}$ & \begin{tabular}{|c|} 
(2) \\
Water \\
Power \\
\% of total \\
\end{tabular} & $\begin{array}{c}\text { (3) } \\
\text { Steam } \\
\text { Power } \\
\text { \% of total } \\
\end{array}$ & $\begin{array}{c}(4) \\
\% \text { Corliss } \\
\text { minus } \\
\% \text { Water }\end{array}$ \\
\hline Textile mill products & 49.9 & 15.6 & 8.5 & 34.3 \\
\hline Primary metal industries & 19.2 & 2.6 & 16.2 & 16.6 \\
\hline Non-manufacturing & 6.0 & 0.6 & 0.0 & 5.4 \\
\hline Apparel & 4.0 & 0.3 & 0.9 & 3.7 \\
\hline Machinery & 5.6 & 2.0 & 4.8 & 3.6 \\
\hline Fabricated metal products & 4.3 & 1.5 & 3.1 & 2.8 \\
\hline Rubber products & 2.3 & 0.2 & 0.3 & 2.1 \\
\hline $\begin{array}{l}\text { Printing, publishing \& allied } \\
\text { products }\end{array}$ & 0.7 & 0.0 & 0.7 & 0.6 \\
\hline Tobacco manufacture & 0.0 & 0.0 & 0.2 & 0.0 \\
\hline $\begin{array}{l}\text { Professional instruments, \& } \\
\text { misc. }\end{array}$ & 0.5 & 0.4 & 0.8 & 0.0 \\
\hline Products of petroleum \& coal & 0.0 & 0.0 & 0.6 & 0.0 \\
\hline Transportation equipment & 0.7 & 0.7 & 1.7 & 0.0 \\
\hline Chemicals \& allied products & 0.6 & 0.6 & 2.5 & -0.1 \\
\hline Furniture \& fixtures & 0.7 & 1.1 & 1.5 & -0.4 \\
\hline Stone, clay \& glass products & 0.3 & 0.8 & 2.1 & -0.5 \\
\hline Leather \& leather products & 0.1 & 1.4 & 2.3 & -1.3 \\
\hline Pulp, paper \& allied products & 1.0 & 3.9 & 1.1 & -2.8 \\
\hline Lumber \& wood products & 1.7 & 31.4 & 31.8 & -29.7 \\
\hline Food \& kindred products & 2.5 & 36.8 & 19.3 & -34.4 \\
\hline Herfindhal index & 30.0 & 26.2 & 17.8 & \\
\hline
\end{tabular}

*The data for steam and water power, from Fenichel (1960). 


\begin{tabular}{|l|c|c|c|c|c|c|}
\hline \multicolumn{7}{|c|}{ Table 3 } \\
\multicolumn{7}{|c|}{$\begin{array}{c}\text { And of Water Mills (1880) } \\
\text { (sorted by Corliss' HP) }\end{array}$} \\
\hline & \multicolumn{7}{|c|}{ Corliss Engines } & \multicolumn{3}{c|}{ Water Mills } \\
\hline & $\begin{array}{c}\text { \# of } \\
\text { Buyers }\end{array}$ & HP & \% of HP & $\begin{array}{c}\text { Number } \\
\text { of Mills }\end{array}$ & HP & \% of HP \\
\hline Massachusetts & 75 & 14,162 & $30.6 \%$ & 1,799 & 123,432 & $18.2 \%$ \\
\hline Pennsylvania & 62 & 11,160 & $24.1 \%$ & 3,825 & 87,591 & $12.9 \%$ \\
\hline Rhode Island & 50 & 10,795 & $23.3 \%$ & 121 & 9,203 & $1.4 \%$ \\
\hline New York & 34 & 5,747 & $12.4 \%$ & 4,205 & 172,591 & $25.4 \%$ \\
\hline Connecticut & 12 & 1,560 & $3.4 \%$ & 1,265 & 64,422 & $9.5 \%$ \\
\hline New Jersey & 9 & 1,260 & $2.7 \%$ & 869 & 28,235 & $4.2 \%$ \\
\hline New Hampshire & 5 & 980 & $2.1 \%$ & 1,275 & 73,480 & $10.8 \%$ \\
\hline Maine & 2 & 250 & $0.5 \%$ & 883 & 65,416 & $9.6 \%$ \\
\hline Maryland & 1 & 200 & $0.4 \%$ & 749 & 17,065 & $2.5 \%$ \\
\hline Delaware & 1 & 175 & $0.4 \%$ & 132 & 4,819 & $0.7 \%$ \\
\hline Vermont & 1 & 50 & $0.1 \%$ & 698 & 32,048 & $4.7 \%$ \\
\hline
\end{tabular}


Table 4

"Adoption" of Corliss Engines and Watermills, by County*

\begin{tabular}{|l|c|c|c|c|c|c|}
\hline \multicolumn{7}{|c|}{ Negative Binomial Count-QML } \\
\hline & Corliss & Water & Corliss & Water & Corliss & Water \\
\hline constant & -4.4 & 3.7 & -4.2 & 3.8 & -3.4 & 3.9 \\
& $(-7.8)$ & $(13.2)$ & $(-7.4)$ & $(13.4)$ & $(-6.9)$ & $(17.4)$ \\
\hline Population & 0.09 & 0.05 & 0.07 & 0.06 & 0.10 & 0.05 \\
& $(4.8)$ & $(0.9)$ & $(3.0)$ & $(1.0)$ & $(3.5)$ & $(0.9)$ \\
\hline Capital invested in & 0.04 & 0.005 & & & 0.04 & 0.006 \\
Manufct. per capita & $(4.3)$ & $(1.5)$ & & & $(5.2)$ & $(1.5)$ \\
\hline Employment in & & & 22.8 & 0.86 & & \\
Manufct. per capita & & & $(4.2)$ & $(0.4)$ & & \\
\hline Books in Public & 1.82 & 0.31 & 1.77 & 0.31 & & \\
Libraries per capita & $(2.7)$ & $(0.8)$ & $(2.6)$ & $(0.84)$ & & \\
\hline \# of Public Libraries & & & & & 0.37 & 0.11 \\
per capita & & & & & $(2.5)$ & $(2.0)$ \\
\hline $\begin{array}{l}\text { LR index } \\
\text { (Pseudo R }{ }^{2} \text { ) }\end{array}$ & 0.52 & 0.02 & 0.51 & 0.02 & 0.52 & 0.02 \\
\hline
\end{tabular}

Z-statistics in parenthesis, based on QML (Huber/White) standard errors

\begin{tabular}{|l|c|c|c|c|}
\hline \multicolumn{4}{|c|}{ (b) Poisson Count (QML), and OLS } \\
\hline & \multicolumn{2}{|c|}{ Poisson } & \multicolumn{2}{c|}{ OLS } \\
\hline Constant & Corliss & Water & Corliss & Water \\
\hline Population & -3.2 & 3.9 & -4.9 & 38.3 \\
& $(-6.8)$ & $(20)$. & $(-6.1)$ & $(2.4)$ \\
\hline Capital invested in & 0.075 & 0.01 & 0.41 & 0.90 \\
Manufct. per capita & $(3.1)$ & $(0.78)$ & $(8.9)$ & $(1.0)$ \\
\hline Books in Public Libraries & 0.03 & 0.004 & 0.03 & 0.39 \\
per capita & $(2.0)$ & $(1.8)$ & $(2.7)$ & $(1.9)$ \\
\hline $\begin{array}{l}\text { LR index (Pseudo R }{ }^{2} \text { ) for } \\
\text { Poisson, R }{ }^{2} \text { for OLS }\end{array}$ & $(2.2)$ & 0.38 & 4.1 & 3.1 \\
\hline
\end{tabular}

For the Possion: z-statistics in parenthesis, based on QML (Huber/White) standard errors; for the OLS: regular t-statistics.

*All regressions include state dummy variables. The data for Corliss are as of 1869 , for watermills as of 1880; each comprises 225 counties/observations. 


\begin{tabular}{|l|l|c|c|}
\hline \multicolumn{5}{|c|}{ Table 5a } \\
\multicolumn{4}{|c|}{ OLS - Average Annual Population Growth, by County } \\
(in percentage points, inc. constant term)
\end{tabular}

t-values in parenthesis, based on White Heteroskedasticity- consistent standard errors

* Excluding outliers: one obs. with pop. growth 1870-1900 $>6 \%$ per year, and one with pop. growth $1860-70>10 \%$ per year. 


\begin{tabular}{|c|c|c|c|c|}
\hline \multicolumn{5}{|c|}{$\begin{array}{c}\text { Table 5b } \\
\text { TSLS - Average Annual Population Growth, by County } \\
\text { Using Predicted Corliss as IV } \\
\text { (in percentage points; } \text { inc. constant term and state dummies) } \\
\end{array}$} \\
\hline & \multicolumn{4}{|c|}{ IV (predicted Corliss) from Adoption Eq.: } \\
\hline $\begin{array}{l}\text { Negative } \\
\text { Binomial }\end{array}$ & Poisson & LS & \begin{tabular}{l|} 
Negative \\
Binomial
\end{tabular} & \\
\hline
\end{tabular}

\begin{tabular}{|l|c|c|c|c|c|}
\hline \# of Water Mills & $\begin{array}{c}-0.002 \\
(-2.9)\end{array}$ & $\begin{array}{c}-0.002 \\
(-2.9)\end{array}$ & $\begin{array}{c}-0.002 \\
(-2.9)\end{array}$ & $\begin{array}{c}-0.002 \\
(-2.8)\end{array}$ & $\begin{array}{c}-0.002 \\
(-2.8)\end{array}$ \\
\hline $\begin{array}{l}\text { \# of Corliss Buyers } \\
\text { (exc. Providence, } R A)\end{array}$ & $\begin{array}{c}0.05 \\
(1.9)\end{array}$ & $\begin{array}{c}0.04 \\
(2.2)\end{array}$ & $\begin{array}{c}0.06 \\
(2.2)\end{array}$ & $\begin{array}{c}0.05 \\
(1.7)\end{array}$ & $\begin{array}{c}0.034 \\
(1.8)\end{array}$ \\
\hline Pop. Growth 1850-70 & & & & 0.35 & 0.35 \\
& & & & $(5.7)$ & $(5.7)$ \\
\hline Pop. Growth 1860-70 & $\begin{array}{c}0.30 \\
(3.7)\end{array}$ & $\begin{array}{c}0.30 \\
(3.7)\end{array}$ & $\begin{array}{c}0.30 \\
(3.7)\end{array}$ & & \\
\hline $\begin{array}{l}\text { Capital invst. in } \\
\text { Manufct. per est. }\end{array}$ & $\begin{array}{c}2.7 \mathrm{E}-05 \\
(2.1)\end{array}$ & $\begin{array}{c}3.0 \mathrm{E}-05 \\
(2.4)\end{array}$ & $\begin{array}{c}2.6 \mathrm{E}-05 \\
(2.1)\end{array}$ & $\begin{array}{c}2.5 \mathrm{E}-05 \\
(2.2)\end{array}$ & $\begin{array}{c}2.7 \mathrm{E}-05 \\
(2.4)\end{array}$ \\
\hline $\begin{array}{l}\text { County Taxes } \\
\text { Per capita }\end{array}$ & $\begin{array}{c}0.10 \\
(1.6)\end{array}$ & $\begin{array}{c}0.11 \\
(1.7)\end{array}$ & $\begin{array}{c}0.10 \\
(1.4)\end{array}$ & $\begin{array}{c}0.08 \\
(1.2)\end{array}$ & $\begin{array}{c}0.08 \\
(1.3)\end{array}$ \\
\hline Obs. & 223 & 223 & 223 & 223 & 223 \\
\hline $\mathbf{R}^{2}$ & 0.48 & 0.48 & 0.48 & 0.52 & 0.52 \\
\hline
\end{tabular}

t-values in parenthesis, based on White Heteroskedasticity- consistent standard errors

* Excluding outliers: one obs. with pop. growth $1870-1900>6 \%$ per year, and one with pop. growth $1860-70>10 \%$ per year. 


\section{Table 6 \\ Scale (HP) of Waterpower* vs. Corliss Establishments \\ (sorted by Corliss' Average HP)}

\begin{tabular}{|l|c|c|c|}
\hline \multirow{2}{*}{ Sector } & \multicolumn{2}{|c|}{ Waterpower } & Corliss \\
\cline { 2 - 4 } & $\begin{array}{c}\text { Number of } \\
\text { Mills }\end{array}$ & $\begin{array}{c}\text { Average } \\
\text { HP }\end{array}$ & $\begin{array}{c}\text { Average } \\
\text { HP }\end{array}$ \\
\hline Primary metal industries & 307 & 50 & 328 \\
\hline Fabricated metal products & 328 & 41 & 293 \\
\hline Textile mill products & 1,271 & 135 & 285 \\
\hline Food and kindred products & 5,342 & 30 & 283 \\
\hline Rubber products & 20 & 120 & 262 \\
\hline Apparel & 181 & 47 & 228 \\
\hline Non-manufacturing & 8 & 26 & 206 \\
\hline Not assigned & $\mathbf{2 7}$ & $\mathbf{2 2}$ & $\mathbf{1 3 5}$ \\
\hline Furniture and fixtures & 430 & 31 & 120 \\
\hline Pulp, paper and allied products & 484 & 147 & 118 \\
\hline Lumber and wood products & 5,724 & 30 & 81 \\
\hline Professional instruments, etc. and & 66 & 24 & 80 \\
\hline miscellaneous & & & \\
\hline Machinery & 785 & 33 & 77 \\
\hline Chemicals and allied products & 155 & 47 & 63 \\
\hline Stone, clay and glass products & 133 & 29 & 55 \\
\hline Transportation equipment & 119 & 25 & 48 \\
\hline Leather and leather products & 376 & 26 & 40 \\
\hline Printing, publishing and allied products & 44 & 20 & 38 \\
\hline Electric machinery & 11 & 70 & - \\
\hline Products of petroleum and coal & 3 & 21 & - \\
\hline Tobacco manufacture & 15 & 18 & - \\
\hline Total & $\mathbf{1 5 , 8 2 9}$ & $\mathbf{4 3}$ & $\mathbf{1 8 3}$ \\
\hline
\end{tabular}

*The data for waterpower are from the 1880 census, and refers to the 11 North and MidAtlantic States 
Figure 1

Power Use in US Manufacturing

(in thousand horsepower)

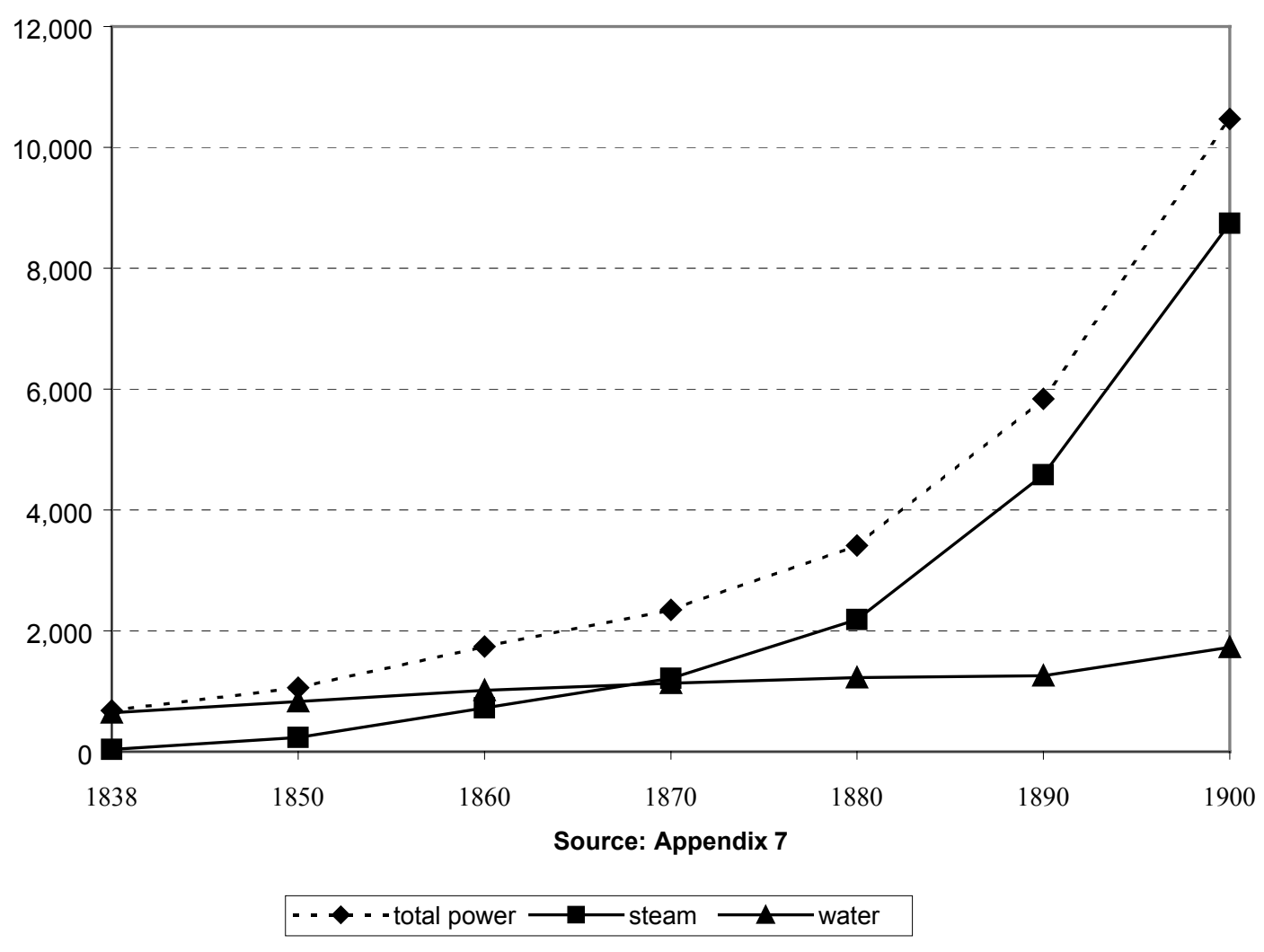


Figure 2

Steam and Water Power in New England

(in thousand horsepower)

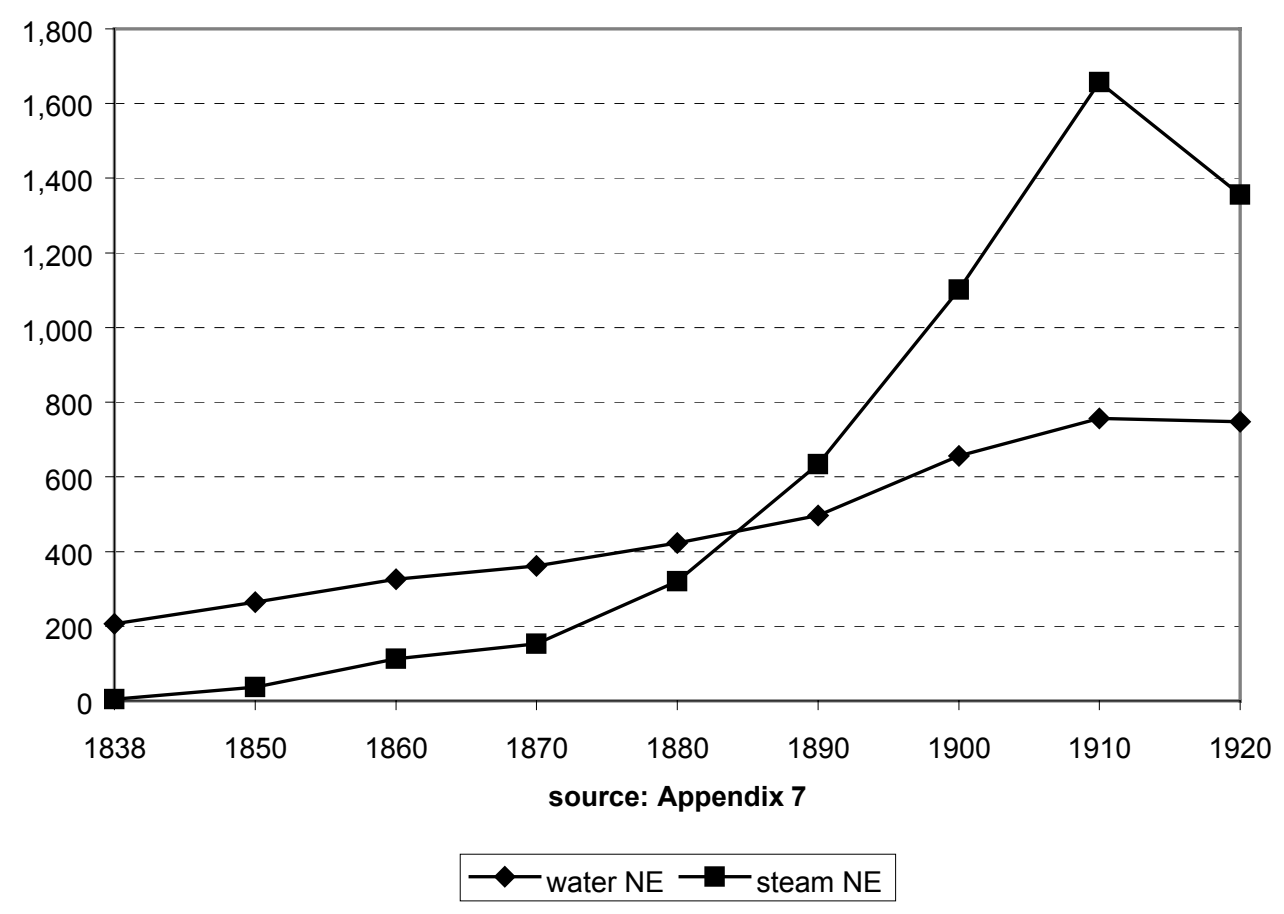


Figure 3

Steam vs. Water Power: New England and Rest of US $\%$ of total power sources*

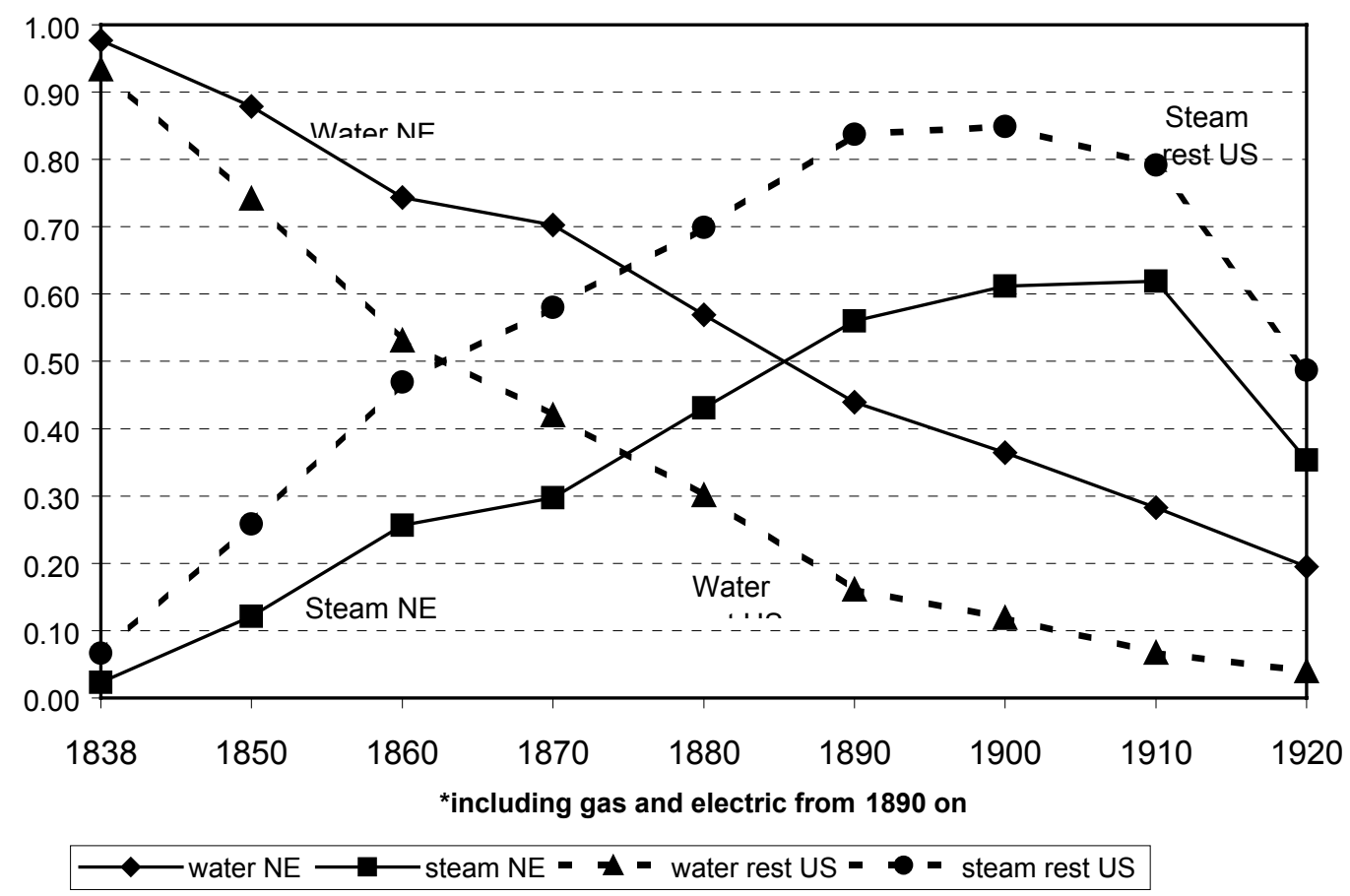

